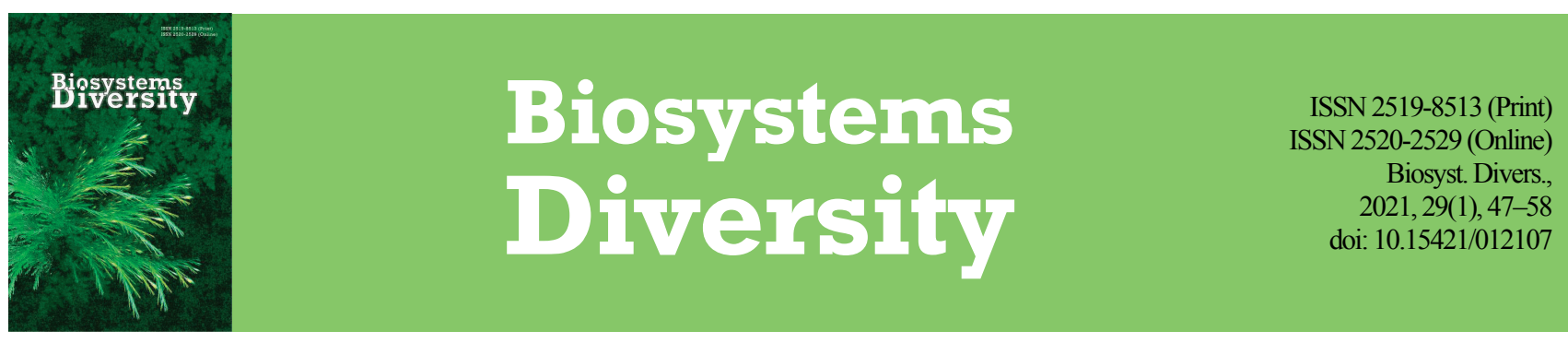

\title{
Current state and long-term changes in the mesozooplankton community of the Ukrainian and Georgian parts of the Black Sea as indicators of its ecological status
}

\author{
Y. V. Kharytonova*, M. V. Nabokin**, M. M. Mgeladze***, P. A. Vadachkoria***, V. G. Dyadichko* \\ *Institute of Marine Biology of the National Academy of Sciences of Ukraine, Odesa, Ukraine \\ **Ukrainian Scientific Center of Ecology of the Sea, Odesa, Ukraine \\ ***Fisheries, Aquaculture and Water Biodiversity Department of National Environmental Agency, Batumi, Georgia
}

Article info
Received 28.01 .2021
Received in revised form
22.02 .2021
Accepted 25.02 .2021

Institute of Marine Biology of the National Academy

of Sciences of Ukraine

Udilnyy lane, 6 ,

Odesa, 65012, Ukraine.

Tel.: + 38-066-509-84-20.

E-mail: kharytono-

vajulia@ukr.net

Ukrainian Scientific Center

of Ecology of the Sea

Frantsuzskyyblv, 89

Odesa, 65009, Ukraine

Tel.: +38-068-813-48-34.

E-mail:

m.nabokin1@gmail.com

Fisheries, Aquaculture and Water Biodiversity

Department of National

Environmental Agency,

Rustavelis st. 51,

Batumi, 6010, Georgia

Tel.:+99-559-140-40-24

E-mail:

marimgeladze@gmail.com

\begin{abstract}
Kharytonova, Y. V., Nabokin, M. V., Mgeladze, M. M., Vadachkoria, P. A., \& Dyadichko, V. G. (2021). Current state and long-term changes in the mesozooplankton community of the Ukrainian and Georgian parts of the Black Sea as indicators of its ecological status. Biosystems Diversity, 29(1), 47-58. doi:10.15421/012107

Water quality assessment is a key task of any measures in the field of water use, environmental management and protection. Thus, it is necessary to conduct systematic monitoring to assess the ecological state in the marine waters and to develop a strategy for its recovery. Anthropogenic impacts of various types leading to eutrophication and pollution of the Black Sea are changing the main characteristics of all components of the aquatic ecosystem. Zooplankton plays a key role in the pelagic food web. This article presents the results of the research on the state of zooplankton which was conducted during the Ukrainian-Georgian expedition in the framework of the international project "Emblas-plus" during 2016, 2017 and 2019. The ecological quality class of the investigated Black Sea waters was determined by the zooplankton integrated index (IZI). In Ukrainian waters in total, 49 taxa of zooplankton were registered. In 2017 taxonomic composition of zooplankton was more diverse (36 taxa in 2016, 35 in 2019). In Georgian waters in 2019, 40 taxa of mesozooplankton were registered, most of them are widespread forms in the Black Sea. The most diverse group is Crustacea (Cladocera and Copepoda).The most prevalent crustaceans were the eurythermic species, an important representative of forage zooplankton - Acartia (Acartiura) clausi Giesbrecht, 1889 and two thermophilic species of Calanoida - Acartia (Acanthacartia) tonsa Dana, 1849 and Centropages ponticus Karavaev, 1895. In Ukrainian waters average abundance and biomass of zooplankton in 2019 was similar to those in 2016 and much higher than in 2017. Dominant taxa and spatial distribution of zooplankton in 2019 were similar to those in 2016 and 2017. Average biomass of forage zooplankton in 2019 was approximately 10 times higher than in 2016 and 2017. In the Georgian coastal waters annual average abundance and biomass of mesozooplankton decreased, due to a sharp decline in the abundance of Noctiluca scintillans (Macartney) Kofoid \& Swezy, 1921. It was found that at most of the stations the dominant role in the formation of zooplankton biomass was played by the organisms of forage zooplankton. By the IZI index, the subdivision Northwestern Black Sea Bays had "Good", "Poor" and "Moderate" water quality in spring, summer and autumn respectively. The subdivision's deepwater shelf and shallow shelf had "Bad" water quality. The subdivision Danube-Dnieper interfluve coastal waters had "High" water quality. The Danube Avandelta area had "High", "Good" and "High" water quality in spring, summer and autumn respectively. The best ecological class status was in 2019 and the worst - in 2016. The main tendencies in changes in the mesozooplankton community in the Black Sea are decrease in the percentage of $N$. scintillans in the total zooplankton biomass and increase in the percentage of Copepoda. Those tendencies indicate decrease in the pressure of the negative eutrophication factor and show positive changes in the forage base of commercial planktophagous fish and the ecological status of the Black Sea waters.
\end{abstract}

Keywords: monitoring of marine water; zooplankton integrated index; water quality; ecological quality class; Copepoda; Cladocera.

\section{Introduction}

Zooplankton plays a key role in the pelagic trophic web, since it binds primary producers of organic matter (phytoplankton) and higher trophic levels (mainly fish) (Koval, 1984). Some zooplankter (organisms of macroplancton) are on the top levels of the pelagic trophic webs (Zaitsev \& Alexandrov, 1997). The participation of zooplankton in the process of water self-cleaning is based on its nutrition upon detritus, bacterio- and phytoplankton, which are the main components of suspended organic matter (Arashkevich et al., 2014). As a result, the water is cleaned of organic and inorganic suspensions, the transparency of water increases, mineralized suspended organic matter is drawn into the cycle of substances, suspensions are deposited and accumulated on the bottom (Zaitsev, 1992; Vinogradov et al., 2006). Together with the other components of the marine ecosystem (phytoplankton, phytobenthos, zoobenthos, bacteria, fungi etc.), the status of the zooplankton can be used to assess the ecological class of water quality (Kharytonova et al., 2020).

Zooplankton is very important since it is not only the secondary producer in food chain but also it is food for fish and shrimp larvae. The exis- tence of zooplankton and its abundance do not only depend on phytoplankton (Stel'makh, 2009). The impact of the hydrographical structure and stress caused by pollution is important as well. Creatures living in aquatic environment lead their existence in a balance of nature. This balance has been changed during the last decades due to the factors such as overfishing, eutrophication, and lack of oxygen. Consequently, some zooplankton species are disappearing or available only in small numbers (Zaitsev \& Alexandrov 1997). In contrast to this, some other organisms are developing and reaching high quantities. In addition to that, the variety and community structure of copepods and cladocerans, whose existence is typical for the Black Sea ecosystem, have changed considerably since the pre-eutrophication period. Many dominant mesozooplankton species, which support the fish stocks, have been replaced by small and less valuable species (Ozdemir \& Ak, 2012).

In the water column, different species of zooplankton occupy certain depths due to temperature, light intensity, feeding, age, reproductive stage and some other biological, chemical and physical factors (Zaitsev, 1993). The domination of dinoflagellates in the Black Sea ecosystem led to a change in the species composition of the zooplankton. Many large species 
of crustacean zooplankton feeding mainly on diatoms were replaced by small opportunistic species. The most important species in the small zooplankton community is Noctiluca scintillans (Macartney) Kofoid \& Swezy, 1921 due to its high abundance and biomass (Nawata \& Sibaoka, 1983; Gordina et al., 2011; Nikishina et al., 2011).

Environmental problems in the Black Sea are serious. The seas shallow, mixed surface waters receive river discharges which are heavily loaded with nutrients containing nitrogen and phosphorus and contaminated with industrial and mining wastes. In addition, coastal industries appear to discharge wastes directly into the sea with little or no treatment. Thus, the water quality of the life-supporting surface layer has seriously deteriorated. Eutrophication (an enrichment in nutrients) presently prevails in many parts of the Black Sea. It has dramatically changed the marine food chain, thus contributing to the demise of the Black Sea fishery and, especially in the northwestern region, to its diminished amenity value (Pokazeev et al., 2021). Different types of pollutants in domestic or industrial discharges have different effects on human health and ecosystems at the point of discharge and in the surrounding environment. This surrounding environment may be very large and may extend beyond international borders (Bat et al., 2009). Continental discharge is one of the main sources of terrigenous sediments, nutrients, and anthropogenic pollution in the sea and can significantly affect seabed morphology, water quality, primary productivity, and fishery in coastal areas (Osadchiev \& Korshenko, 2017).

Environmental studies have become an integral and mandatory part of studying the territory of Ukraine and the adjacent waters of the Black and Azov Seas, the ultimate goal of which is, as a rule, the assessment of the ecological state. Such studies are especially relevant for the coastal zone, which is distinguished by a complex geological structure, an extraordinary variety of natural processes and a powerful anthropogenic load (Loeva et al., 2008; Robu et al., 2015). Traditionally, groups of both planktonic and benthic hydrobionts have been used to monitor the quality of the marine environment. For coastal ecosystems that are under much larger anthropogenic loading than the open sea, priority is given to the fixed plant and animal species as biological indicators. For open waters, biological factors of zooplankton are more important (Öztürk ta al., 1997; O’Higgins et al., 2014). Criteria elements means the components of an ecosystem, in particular its biological elements (species, habitats and their grouping), or aspects of pressure on the marine environment (biological, physical, substances, debris and energy) that are evaluated against each criterion. In accordance with the requirements of the EU Water Directive (Directive 2000/60/EC) and the Marine Strategy of the EU Water Directive (Directive 2008/56/EC) for the classification and assessment of the reliability of various indicators it was shown that there is a difference in the priority of indicators for open and coastal waters (Rudneva \& Petzold-Bradley, 2011).

Environmental impact assessment is usually defined as a mandatory assessment procedure that analyzes and evaluates the impacts that human activities can have on the environment (Moncheva et al., 2002; Moncheva et al., 2012). According to the zooplankton indicators, the ecological quality class of the studied Black Sea waters are determined on a 5 point quality scale according to the standards of Water Framework Directive of EU: high, good, moderate, poor and bad (Kharytonova, 2019; Kharytonova et al., 2020).

The purposes of the present report are to give qualitative and quantitative assessment of the zooplankton community in the Black Sea waters of Ukraine and Georgia, to conduct comparative analysis of the years 20162019 and earlier historical data and to assess the ecological status class using the ecological quality ratio index (IZI) according to the standards of MSFD and WFD and to describe long-term changes in the mesozooplankton community in the Black Sea.

\section{Materials and methods}

Sampling and assessment of the quality of the aquatic environment of the Black Sea based on zooplankton indicators took place within the framework of the international project "Emblas-plus" during the UkrainianGeorgian expedition (NPMS and JBSS) during 2016, 2017 and 2019.

In Ukrainian coastal and shelf waters during the period 2016, 2017 and 2019 mesozooplankton samples were taken at 25,15 and 20 stations respectively. The historical data for the years 2006-2019 provided by IMB and UkrSCES were analyzed too (Fig. 1).

In Georgian waters data collection was carried out within the National Monitoring Programme on permanent stations situated in Batumi area, inside Batumi Port and near Green Cape each month during last three years 2017-2019. Additionally samples were taken at six transects on the Georgian Shelf starting from the towns Gonio, Batumi, Chakvi, Kobuleti, Poti and Anaklia during the two expeditions. One of them was organized by the project EMBLAS-II in May 2016, and the other one in the same season of 2018 under the national monitoring. The open sea samples were taken during EMBLAS-II (2017) and EMBLAS-Plus (2019) JOSS expeditions at 4 stations (Fig. 2).
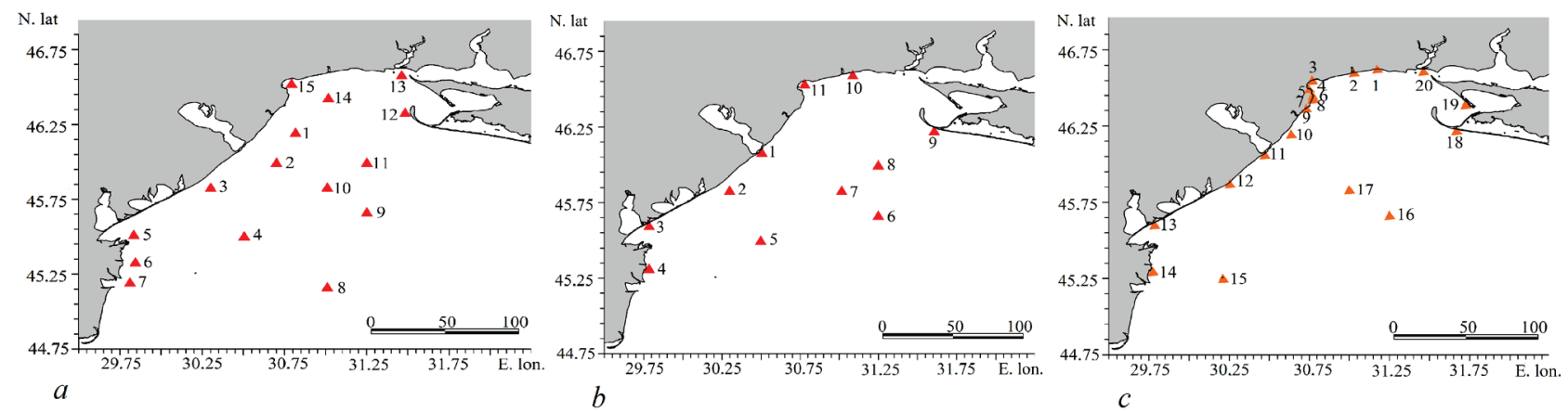

Fig. 1. Zooplankton sampling map in Ukrainian coastal and shelf waters: $a-2016, b-2017, c-2019$
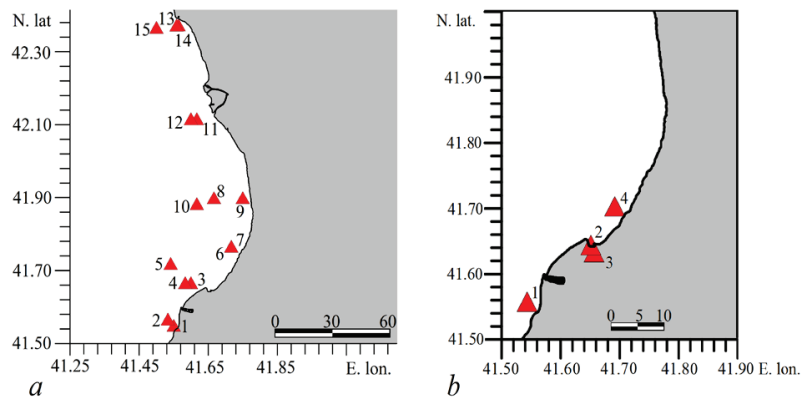

Fig. 2. Zooplankton sampling maps in Georgian waters: $a-2016, b-2017$ and 2019
In open waters of the Black Sea in 2016-2019 the samples were taken at 25, 12 and 15 stations respectively (JOSS GE-UA-cruises). Each cruise route consisted of two transects. First working transect (Gelendzhik) started from the Gelendzhik shelf area and finished in the sea center in 95 miles offshore. This transect ended in the most probable position of the center of the eastern cyclonic gyre consisting of 14 stations starting from seabed $500 \mathrm{~m}$. No stations are located on the shelf because the shelf transect in this area will be explored during the National Monitoring Programmer (Fig. 3).

In all expeditions mesozooplankton samples were taken using a standard Juday plankton net with the mouth area of $0.1 \mathrm{~m}^{2}$ and mesh size $150 \mu \mathrm{m}$. Sometimes the small net with mesh size $100 \mu \mathrm{m}$ was used at the North-Eastern Shelf shallow waters. Samples were fixed with buffered formaldehyde solution ( $4 \%$ final concentration). The samples were pro- 
cessed under binocular microscope according the standard methodology for zooplankton studies in the Black Sea (Salazkin, 1984).
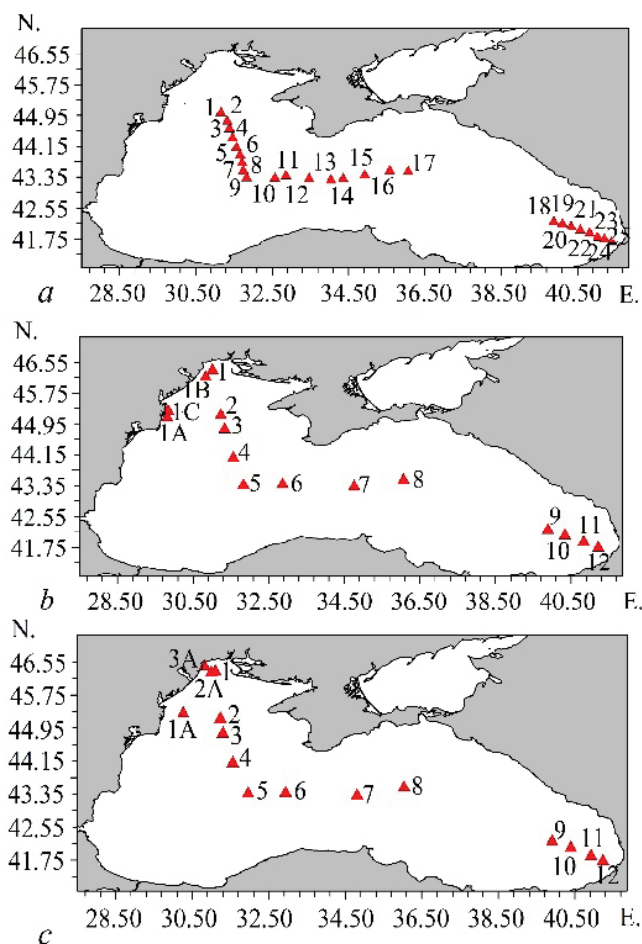

Fig. 3. Zooplankton sampling maps in open waters of the Black Sea: $a-2016, b-2017, c-2019$
The qualitative and quantitative indicators of zooplankton were obtained and species composition, abundance and biomass of different taxa or groups were determined. Species were identified according to identification guides by Morduhay-Boltovskoy (Mordukhai-Boltovsky, 1968, 1969, 1972; Kharytonova, 2019; Kharytonova \& Nabokin, 2020).

It is advisable to use the following metrics of mesozooplankton of the Black Sea as ecological indicators in the environmental monitoring (Aleksandrov \& Kharytonova, 2019): total biomass of zooplankton (B, $\mathrm{mg} / \mathrm{m}^{3}$ ), biomass of $N$. scintillans (\% of total biomass), Copepoda biomass ( $\%$ of total biomass), jellyfish biomass ( $\%$ of total biomass), Shannon number index.

The preference should be given to integral indices based on all the above characteristics. The integral indicator of zooplankton status $\left(\mathrm{K}_{\mathrm{f}}\right)$ is calculated by the formula (Kharytonova \& Nabokin, 2020):

$$
\mathrm{K}_{\mathrm{f}}=\left(\mathrm{K}_{\mathrm{imax}}\right)^{0.5} *\left(\mathrm{~K}_{\mathrm{a} 1} * \mathrm{~K} 2_{\mathrm{a} 2} * \mathrm{~K} 3_{\mathrm{a} 3} * \mathrm{~K} 4_{\mathrm{a} 4} * \mathrm{~K} 5_{\mathrm{a} 5}\right)^{1 / 2 \mathrm{n}} \text {, }
$$

where $\mathrm{K} 1, \mathrm{~K} 2, \mathrm{~K} 3, \mathrm{~K} 4, \mathrm{~K} 5$ are metrics (different characteristics of zooplankton), a1, a2, a3, a4, a5 are the weights of the metrics; $n$ is the number of metrics. Conditions: $0<\mathrm{Ki} \leq 1$ and $0<\mathrm{ai} \leq 100$.

Since the integral indicator of mesozooplankton status should reflect the state of the aquatic environment for the protection of biodiversity, the weighting coefficients for each metric should correlate with Shannon by number $(\mathrm{H})$. The weight value of Shannon number index itself was assumed to be 0.9 because it could not be equal to one (Kharytonova et al., 2020). The quality of the aquatic environment was analyzed based on the results of long-term monitoring of zooplankton status in the Ukrainian part of the Black Sea and in the Danube Delta (Tables 1 and 2). Water quality was defined for different seasons by five-point scale of ecological status from excellent to bad (Kharytonova \& Nabokin, 2020). To assess the ecological class of water quality for the waters of the Black and Azov Seas, integral indicators were calculated in accordance with this methodology and the quality was defined by five-point scale from bad to high (Borja et al., 2006; Atkins et al., 2011; Jeppesen et al., 2011).

Table 1

The value of the integral mesozooplankton (IZI) status indicator for determining the quality of Ukrainian marine waters (Kharytonova \& Nabokin, 2020)

\begin{tabular}{|c|c|c|c|c|c|c|}
\hline \multirow{2}{*}{ Subregion } & \multirow{2}{*}{ Season } & \multicolumn{5}{|c|}{ Sea water quality } \\
\hline & & high & good & moderate & poor & bad \\
\hline \multirow{4}{*}{$\begin{array}{l}\text { Coastal waters, } \\
\text { Danube area }\end{array}$} & spring & $>0.939$ & $0.939-0.925$ & $0.924-0.915$ & $0.914-0.881$ & $<0.881$ \\
\hline & summer & $>0.667$ & $0.667-0.631$ & $0.630-0.565$ & $0.564-0.487$ & $<0.487$ \\
\hline & autumn & $>0.910$ & $0.910-0.899$ & $0.898-0.890$ & $0.889-0.867$ & $<0.867$ \\
\hline & winter & $>0.743$ & $0.743-0.733$ & $0.732-0.709$ & $0.708-0.699$ & $<0.699$ \\
\hline \multirow{4}{*}{$\begin{array}{l}\text { Coastal waters, } \\
\text { Dnestrovsko-Dnieper area }\end{array}$} & spring & $>0.900$ & $0.900-0.883$ & $0.882-0.863$ & $0.862-0.789$ & $<0.789$ \\
\hline & summer & $>0.215$ & $0.215-0.167$ & $0.166-0.094$ & $0.093-0.054$ & $<0.054$ \\
\hline & autumn & $>0.871$ & $0.871-0.849$ & $0.848-0.841$ & $0.840-0.827$ & $<0.827$ \\
\hline & winter & $>0.837$ & $0.837-0.804$ & $0.803-0.789$ & $0.788-0.651$ & $<0.651$ \\
\hline \multirow{4}{*}{$\begin{array}{l}\text { Shelf zone, surface layer } \\
(0-10 \mathrm{~m}) \text {, Danube area }\end{array}$} & spring & $>0.927$ & $0.927-0.917$ & $0.916-0.899$ & $0.898-0.864$ & $<0.864$ \\
\hline & summer & $>0.538$ & $0.538-0.511$ & $0.510-0.477$ & $0.476-0.382$ & $<0.382$ \\
\hline & autumn & $>0.941$ & $0.941-0.928$ & $0.927-0.914$ & $0.913-0.884$ & $<0.884$ \\
\hline & winter & $>0.603$ & $0.603-0.597$ & $0.596-0.593$ & $0.592-0.591$ & $<0.591$ \\
\hline \multirow{3}{*}{$\begin{array}{l}\text { Shelf zone, } \\
\text { surface layer }(0-10 \mathrm{~m}) \text {, } \\
\text { Dniester-Dnipro area }\end{array}$} & spring & $>0.927$ & $0.927-0.912$ & $0.911-0.897$ & $0.896-0.835$ & $<0.835$ \\
\hline & summer & $>0.872$ & $0.872-0.854$ & $0.853-0.828$ & $0.827-0.599$ & $<0.599$ \\
\hline & autumn & $>0.832$ & $0.832-0.713$ & $0.712-0.618$ & $0.617-0.581$ & $<0.581$ \\
\hline \multirow{4}{*}{$\begin{array}{l}\text { Open water, } \\
\text { surface layer }(0-10 \mathrm{~m})\end{array}$} & spring & $>0.864$ & $0.864-0.851$ & $0.850-0.838$ & $0.837-0.806$ & $<0.806$ \\
\hline & summer & $>0.706$ & $0.706-0.686$ & $0.685-0.684$ & $0.683-0.674$ & $<0.674$ \\
\hline & autumn & $>0.463$ & $0.463-0.452$ & $0.451-0.321$ & $0.320-0.129$ & $<0.129$ \\
\hline & winter & $>0.944$ & $0.944-0.928$ & $0.927-0.903$ & $0.902-0.889$ & $<0.889$ \\
\hline \multirow{4}{*}{$\begin{array}{l}\text { Shelf zone and open water, } \\
\text { thermocline zone }(10-25 \mathrm{~m})\end{array}$} & spring & $>0.942$ & $0.942-0.926$ & $0.925-0.911$ & $0.910-0.892$ & $<0.892$ \\
\hline & summer & $>0.647$ & $0.647-0.635$ & $0.634-0.617$ & $0.616-0.602$ & $<0.602$ \\
\hline & autumn & $>0.924$ & $0.924-0.907$ & $0.906-0.895$ & $0.894-0.866$ & $<0.866$ \\
\hline & winter & $>0.396$ & $0.396-0.340$ & $0.339-0.280$ & $0.279-0.268$ & $<0.268$ \\
\hline \multirow{4}{*}{$\begin{array}{l}\text { Open water, } \\
\text { cold intermediate layer } \\
(25-100 \mathrm{~m})\end{array}$} & spring & $>0.940$ & $0.940-0.937$ & $0.936-0.929$ & $0.928-0.918$ & $<0.918$ \\
\hline & summer & $>0.893$ & $0.893-0.876$ & $0.875-0.812$ & $0.811-0.701$ & $<0.701$ \\
\hline & autumn & $>0.949$ & $0.949-0.942$ & $0.941-0.923$ & $0.922-0.891$ & $<0.891$ \\
\hline & winter & $>0.945$ & $0.945-0.943$ & $0.942-0.935$ & $0.934-0.902$ & $<0.353$ \\
\hline
\end{tabular}

For the Georgian waters of the Black Sea the following values of the integral mesozooplankton status indicator were used for assessing the ecological status (Table 3). This ranking was carried out after determining the value of IZI for all observations used in calculations for a specially developed program (Kharytonova \& Nabokin, 2020). Due to the limited amount of data on zooplankton in Georgian coastal and shelf water, readymade thresholds calculated for five categories were used to determine the threshold values between good environmental status (GES) and not good environmental status (NotGES) (O'Higgins et al., 2014). As a result of the merger of statuses "High" and "Good", we established status of GES, and by combining the remaining three categories of "moderate", "poor" and "bad", we determined another status of NotGES.

The results were processed by standard methods with the calculation of $\mathrm{x}$ - mean value, as the sample mean and standard deviation (SD). Dif- 
ferences between variants were considered statistically significant at $\mathrm{P}<$ 0.05 . The difference between the study variants was proved by using ANOVA.

\section{Table 2}

The value of the integral mesozooplankton status indicator for determining the quality of transitional waters of the Ukrainian part of the Danube Delta (Kharytonova, 2019)

\begin{tabular}{lccccc}
\hline Season & High & Good & Moderate & Poor & Bad \\
\hline Spring & $>0.483$ & $0.483-0.437$ & $0.436-0.365$ & $0.364-0.268$ & $<0.268$ \\
Summer & $>0.584$ & $0.584-0.513$ & $0.512-0.411$ & $0.410-0.376$ & $<0.376$ \\
Autumn & $>0.663$ & $0.663-0.620$ & $0.619-0.539$ & $0.538-0.473$ & $<0.473$ \\
Winter & - & - & - & - & -
\end{tabular}

Note:-samples were not taken.

Table 3

The value of the integral mesozooplankton status indicator for determining the quality of Georgian waters

\begin{tabular}{lccccc}
\hline \multicolumn{1}{c}{ Subregion } & High & Good & Moderate & Poor & Bad \\
\hline $\begin{array}{l}\text { Marine } \\
\text { coastal waters }\end{array}$ & $>0.844$ & $0.844-0.543$ & $0.542-0.264$ & $0.263-0.141$ & $<0.140$ \\
Transition waters & $>0.846$ & $0.846-0.584$ & $0.583-0.301$ & $0.300-0.128$ & $<0.128$ \\
\hline
\end{tabular}

\section{Results}

In Ukrainian waters in total 49 taxa of zooplankton were registered: Protista-2, Animalia: Coelenterata-2, Ctenophora -2 (Tentaculata-1), Nematoda - 1, Potifera - 4, Annelida (Polychaeta - 4), Mollusca (Gastropoda -1 , Bivalvia -1 ), Chaetognatha -1 , Chordata - 3, Arthropoda (Crustacea -26 , including Branchiopoda: Cladocera -8 , Maxillopoda: Copepoda - 14, Cirripedia - 1, Ostracoda - 1, Malacostraca: Isopoda - 1, Decapoda - 1, Cumacea -1 taxon). Most of them belong to the typical inhabitants of the sea waters of the Black sea. Bosmina longirostris O. F. Müller, 1776 and Cornigerius maeoticus Pengo, 1879 live primarily in oligohaline and fresh waters. Holoplankton includes 35 taxa, meroplankton - 14 taxa. Most of them belong to the forage zooplankton for fish. In 2017 taxonomic composition of zooplankton was more diverse (36 taxa in 2016, 35 in 2019). In Georgian waters 40 taxa of the mesozooplankton were listed, most of them are widespread forms in the Black Sea. Among them, the most diverse group is Crustacea (17 species), which amounts to $45-50 \%$ of total zooplankton species, 12 of which are Copepoda and other 5 species are Cladocera. The most prevalent crustaceans are the eurythermic species, important representative of forage zooplankton - Acartia (Acartiura) clausi Giesbrecht, 1889 and two thermophilic species of Calanoida - Acartia (Acanthacartia) tonsa Dana, 1849 and Centropages ponticus Karavaev, 1895. Meroplankton represented by 11 species (29-32\% of total zooplankton species), is also one of the most diverse groups. It shall be noted that only few species are discovered from the other groups.

Indicator species of the state of the marine environment have been increased in coastal waters of Ukraine and Georgia over the past years, among others, Penilia avirostris Dana, 1849, Pseudoevadne tergestina Claus, 1877, Evadne spinifera P. E. Müller, 1867, C. ponticus and Decapoda larvae Latreille, 1802. It should be especially noted that in 20172019 an indicator species of copepoda Monstrilla grandis Giesbrecht, 1891 was observed at Sarpi and Green Cape stations, for the first time in Georgia, which indicates the current positive trends in the Black Sea ecosystem.

In the deep basin of Ukrainian and Georgian waters 34 taxa of zooplankton were registered in total: Protista -1 , Coelenterata - 2, Ctenophora-2, Potifera-2, Annelida-2, Mollusca (Gastropoda-1, Bivalvia-1), Chaetognatha -1 , Chordata -2 , Arthropoda (Crustacea - 20, including Branchiopoda: Cladocera - 5, Maxillopoda: Copepoda - 12, Cirripedia 1; Malacostraca: Isopoda - 1, Decapoda - 1 taxon). Most of them belong to the typical inhabitants of the sea waters of the Black Sea. Calanipeda aquaedulcis Kritschagin, 1873 and Eurytemora velox Lilljeborg, 1853 live primarily in estuary regions, Asplanchna brightwelli Gosse, 1850 is mainly a freshwater or oligohaline dweller. Holoplankton includes 26 taxa, meroplankton -8 taxa. Most of registered taxa belong to the forage zooplankton for fish.

In the north-western part of the Black Sea and Zernov's Phyllophora Field 49 taxa of zooplankton were registeredin total: Protista - 3, Coelenterata - 2, Ctenophora - 2 (Tentaculata - 1), Potifera - 3, Annelida (Polychaeta - 4), Chaetognatha - 1, Chordata - 3, Mollusca (Gastropoda - 1, Bivalvia - 1), Arthropoda (Crustacea - 12, including Branchiopoda: Cladocera - 7, Maxillopoda: Copepoda - 14, Cirripedia - 1; Malacostraca: Amphipoda - 1, Decapoda - 1, Cumacea - 1), Chelicerata (Acari - 1 taxon). Most of them belong to the typical inhabitants of the sea waters of the Black Sea. B. longirostris and C. maeoticus live primarily in oligohaline and fresh waters. Holoplankton includes 35 taxa, meroplankton 14 taxa. Most of them belong to the forage zooplankton for fish.

In Ukrainian waters average abundance and biomass of zooplankton in $2019\left(19,642 \mathrm{ind} . / \mathrm{m}^{3}\right.$ and $\left.281.14 \mathrm{mg} / \mathrm{m}^{3}\right)$ was similar to those in 2016 $\left(10,299 \mathrm{ind} / \mathrm{m}^{3}\right.$ and $\left.182.62 \mathrm{mg} / \mathrm{m}^{3}\right)$ and much higher than in 2017 (1714 ind. $/ \mathrm{m}^{3}$ and $29.99 \mathrm{mg} / \mathrm{m}^{3}$ ). Dominant taxa and spatial distribution of zooplankton in 2019 was similar to those in 2016 and 2017. Average biomass of forage zooplankton in 2019 was approximately 10 times higher than in 2016 and 2017 (23.8 and $21.4 \mathrm{mg} / \mathrm{m}^{3}$ respectively, Fig. 4). So, we can see the positive changes in a state of the forage base of planktophagous fishes during the last few years.
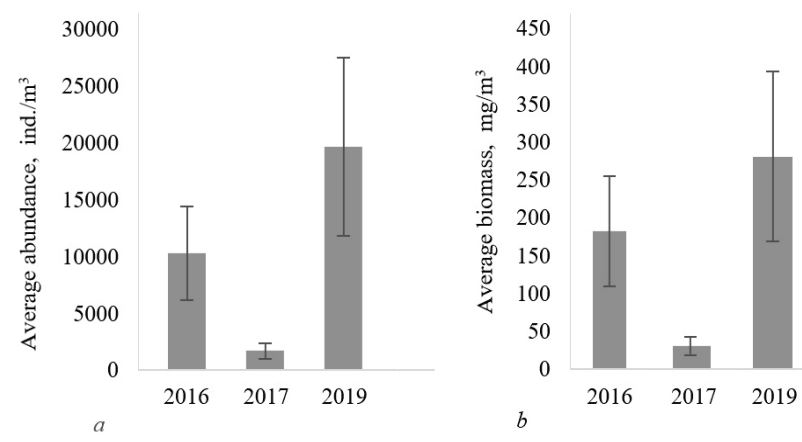

Fig. 4. Average abundance and biomass of forage zooplankton in Ukrainian waters in 2016-2019: $a$ - average abundanc $\left(\mathrm{N}\right.$, ind. $\left./ \mathrm{m}^{3}\right)$, $b$-average biomass $\left(\mathrm{B}, \mathrm{mg} / \mathrm{m}^{3}\right)$; in $2016-\mathrm{n}=15$; in $2017-\mathrm{n}=11$;

$$
\text { in } 2019-\mathrm{n}=20 ; \mathrm{x} \pm \mathrm{SD}
$$

The Georgian coastal waters were sampled each two months during period of 2017-2019 and annual average abundance and biomass of mesozooplankton during this time decreased, due to a sharp decline in the abundance of $N$. scintillans. In the first year average abundance was very high and reached $8,879 \mathrm{ind} . / \mathrm{m}^{3}$, while the biomass reached $245.8 \mathrm{mg} / \mathrm{m}^{3}$. These figures decreased almost two times in the next year $\left(3946 \mathrm{ind} . \mathrm{m}^{3}\right.$ and $116.8 \mathrm{mg} / \mathrm{m}^{3}$ ), while in 2019 it reduced again and amounted to $2074 \mathrm{ind} . \mathrm{m}^{3}$ and $80.7 \mathrm{mg} / \mathrm{m}^{3}$ (Fig. 5).

Average number of zooplankton in the deep basin of Ukrainian and Georgian waters was 4788 ind $/ \mathrm{m}^{3}$, biomass $337.41 \mathrm{mg} / \mathrm{m}^{3}$. The number and biomass of zooplankton clearly decreased from the water-surface to the depth. In the upper mixed layer average number of zooplankton was $10,252 \mathrm{ind} . \mathrm{m}^{3}$, biomass $742.83 \mathrm{mg} / \mathrm{m}^{3}$. At the thermocline the average number and biomass of zooplankton were approximately 4-5 times less than in the upper mixed layer $-2,539 \mathrm{ind} / \mathrm{m}^{3}$ and $140.84 \mathrm{mg} / \mathrm{m}^{3}$ respectively. Under the thermocline, the average number and biomass of zooplankton were 1.8-3.5 times less than at the thermocline $-715 \mathrm{ind} . \mathrm{m}^{3}$ and $75.29 \mathrm{mg} / \mathrm{m}^{3}$ respectively. The largest number and biomass of zooplankton were registered in the Zmeiny Island region (station JOSS GE-UA 2019 la) $-32,505 \mathrm{ind} . \mathrm{m}^{3}$ and $3445.42 \mathrm{mg} / \mathrm{m}^{3}$. Minimal number and biomass of zooplankton was registered in the open marine waters at the station JOSS GE-UA 20195 at the thermocline layer -203 ind. $/ \mathrm{m}^{3}$ and $3.99 \mathrm{mg} / \mathrm{m}^{3}$. At most of the stations dominant taxa by number and biomass were Copepoda (Acartia spp., Pseudocalanus elongates Brady, 1865, Calanus euxinus Hulsemann, 1991, Oithona davisae Ferrari F. D. \& Orsi, 1984) Cladocera (P. avirostris) and fish eggs. In the Georgian waters at the station JOSS GE-UA 20199 and at the thermocline layer of JOSS GE-UA 201911 dominant taxa by biomass were Ctenophora, 
which formed $90-94 \%$ of total zooplankton biomass (103 of 178 and 177 of $188 \mathrm{mg} / \mathrm{m}^{3}$, Fig. 6).

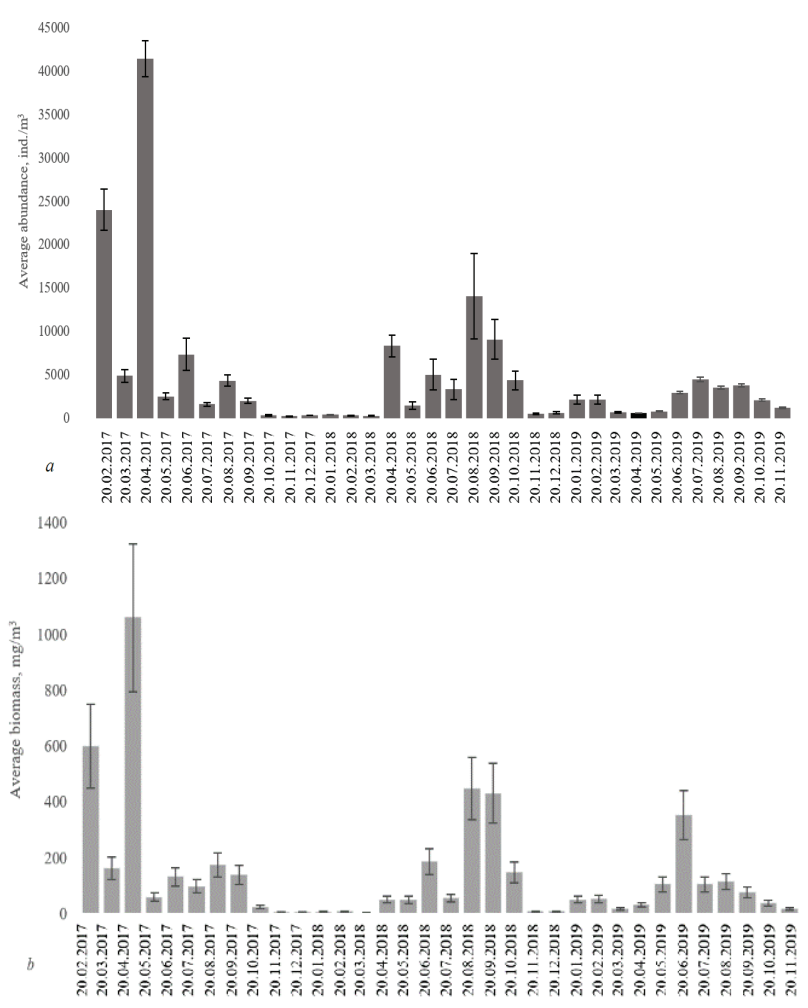

Fig. 5. The seasonal dynamic of zooplankton abundance $(a)$ and biomass $(b)$ on the Black Sea Georgian Coast in 2017-2019:

$$
\mathrm{x} \pm \mathrm{SD} ; \mathrm{n}=3
$$

Most of registered taxa of zooplankton belong to the forage base for fish. At most of the stations organisms of the forage zooplankton played a dominant role in forming of zooplankton biomass. Average biomass of the forage zooplankton was $315.33 \mathrm{mg} / \mathrm{m}^{3}$, so the status of the forage base of planktophagous fishes was mainly good. Maximal biomass of the forage zooplankton $-3443.95 \mathrm{mg} / \mathrm{m}^{3}$ was registered at the station JOSS GE-UA 2019 1a-Zmeiny Island region (Fig. 7).

Most of registered taxa of zooplankton belong to the forage base for fish. At all the stations organisms of the forage zooplankton played a dominant role in forming of zooplankton biomass. Percentage of the nonforage zooplankton in the total biomass was less than $23 \%$. Average biomass of the forage zooplankton was $220 \mathrm{mg} / \mathrm{m}^{3}$, so the status of forage base of planktophagous fishes was relatively good. Maximal biomass of the forage zooplankton $-1524.08 \mathrm{mg} / \mathrm{m}^{3}$ was registered at the station MMS-19-18 (Tendra Island). Minimal biomass of the forage zooplankton $5.02 \mathrm{mg} / \mathrm{m}^{3}$ was registered at the station MMS-19-9 in the Dniester region (Fig. 9).

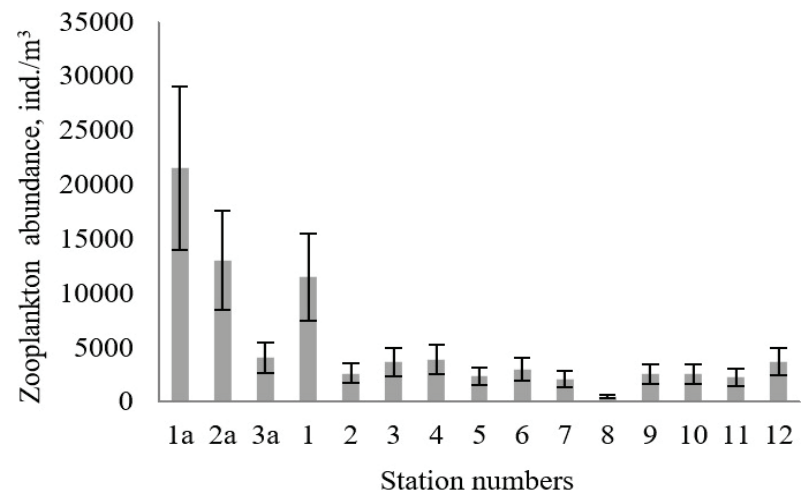

Fig. 6. Zooplankton abundance (ind. $/ \mathrm{m}^{3}$ ) at different stations of JOSS cruise in the open part of the Black Sea, August 2019: axis X - numbers of stations, axis $\mathrm{Y}-$ zooplankton abundance (ind. $\left./ \mathrm{m}^{3}\right) ; \mathrm{x} \pm \mathrm{SD} ; \mathrm{n}=3$

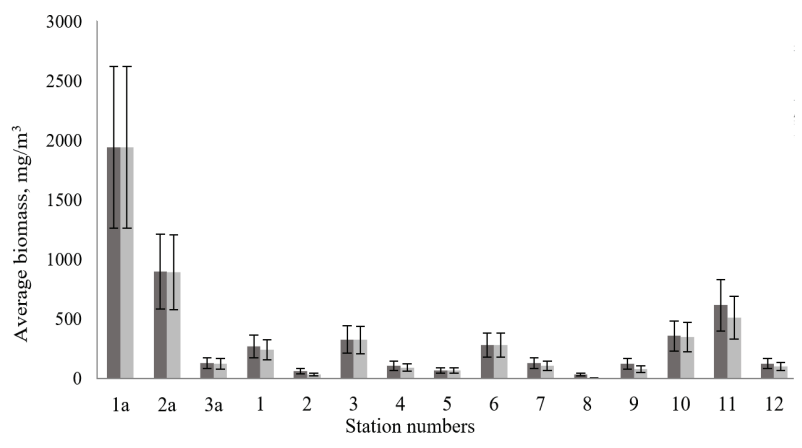

Fig. 7. Total and forage zooplankton biomass $\left(\mathrm{mg} / \mathrm{m}^{3}\right)$ at different stations of JOSS cruise in the open part of the Black Sea, August 2019: axis $\mathrm{X}$ - numbers of stations on maps, axis $\mathrm{Y}$-average biomass $\left(\mathrm{mg} / \mathrm{m}^{3}\right)$; gray dark - total zooplankton biomass $\left(\mathrm{mg} / \mathrm{m}^{3}\right)$, gray light - forage zooplankton biomass $\left(\mathrm{mg} / \mathrm{m}^{3}\right) ; \mathrm{x} \pm \mathrm{SD} ; \mathrm{n}=3$

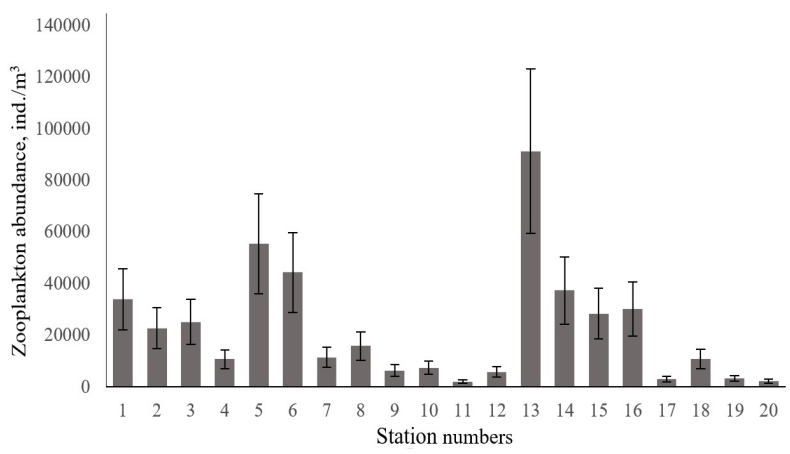

Fig. 8. Zooplankton abundance in the north-western part of the Black Sea in 2019 (ind. $/ \mathrm{m}^{3}$ ): axis X - numbers of stations: 1, 2, 19, 20 -Dnieper region $(n=12), 3-8$ - Odessa Bay $(n=6), 9-12-$ Dniester region $(n=6)$,

13, 14 - Danube region $(n=6), 15-Z$ meiny island $(n=3), 16,17$ -

Zernov's Phyllophora field $(n=6), 18$ - Tendra Spit region $(n=6)$; axis $\mathrm{Y}$-zooplankton abundance (ind. $\left./ \mathrm{m}^{3}\right) ; \mathrm{x} \pm \mathrm{SD}$

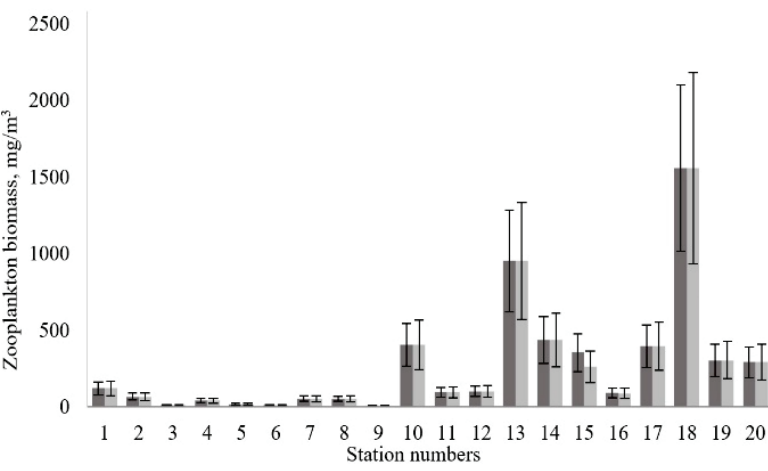

Fig. 9. Total and forage zooplankton biomass in the north-western part of the Black Sea in 2019: axis X-numbers of samples and stations:

$1,2,19,20$ - Dnieper region $(n=12), 3-8-$ Odessa Bay $(n=6)$,

9-12-Dniester region $(n=6), 13,14-$ Danube region $(n=6)$,

15 -Zmeiny Island $(n=3), 16,17$-Zernov's Phyllophora field $(n=6)$, 18 - Tendra Spit region $(\mathrm{n}=3)$; axis $\mathrm{Y}$-zooplankton biomass $\left(\mathrm{mg} / \mathrm{m}^{3}\right)$; Dark grey - total zooplankton biomass $\left(\mathrm{mg} / \mathrm{m}^{3}\right)$, light grey - forage zooplankton biomass $\left(\mathrm{mg} / \mathrm{m}^{3}\right) ; \mathrm{x} \pm \mathrm{SD}$

In the north-western part of the Black Sea and Zernov's Phyllophora Field, the average number of zooplankton was 19,642 ind. $/ \mathrm{m}^{3}$, biomass $281.14 \mathrm{mg} / \mathrm{m}^{3}$. The highest average number and biomass of zooplankton was registered in the Dnieper area $-52,735 \mathrm{ind} . \mathrm{m}^{3}$ and $715.53 \mathrm{mg} / \mathrm{m}^{3}$ respectively. In the Danube region average number and biomass of the zooplankton were similar to those in the Dnieper region - 49,702 ind. $/ \mathrm{m}^{3}$ and $692.33 \mathrm{mg} / \mathrm{m}^{3}$ respectively. In the Dniester area average number and biomass of zooplankton were lower than in two previous regions $17,747 \mathrm{ind} . / \mathrm{m}^{3}$ and $96.65 \mathrm{mg} / \mathrm{m}^{3}$ respectively. In the zone of mixed waters the number of zooplankton was an order of magnitude less than in pre- 
vious aquatoria $-7,988 \mathrm{ind} . \mathrm{m}^{3}$ but the biomass was higher than in the Dniester region but lower than in the Danube and Dnieper regions $329.18 \mathrm{mg} / \mathrm{m}^{3}$ (Fig. 8). At most of the stations the dominant taxa by number and biomass were Copepoda (Acartia spp., O. davisae) Cladocera ( $P$. avirostris) and larvae of benthic invertebrates.

In comparison with data for the years 2016 and 2017, in 2019 taxonomic composition of zooplankton was more diverse (27 taxa in 2016, 26 in 2017). Comparing data for 2016 and 2017 we can see that the average number and biomass of zooplankton in 2019 was similar to those in 2016 $\left(10,299 \mathrm{ind} / \mathrm{m}^{3}\right.$ and $\left.182.62 \mathrm{mg} / \mathrm{m}^{3}\right)$ and much more higher than in 2017 $\left(1,714 \mathrm{ind} / \mathrm{m}^{3}\right.$ and $\left.29.99 \mathrm{mg} / \mathrm{m}^{3}\right)$. Dominant taxa and spatial distribution of zooplakton in 2019 was similar to those in 2016 and 2017. In comparison with data for 2016 and 2017 years, in 2019 average biomass of forage zooplankton was approximately 10 times higher than in 2016 and 2017 $\left(23.8 \mathrm{mg} / \mathrm{m}^{3}\right.$ and $21.4 \mathrm{mg} / \mathrm{m}^{3}$ respectively).

According to the zooplankton metrics and IZI integral index, in 2019 most of investigated Ukrainian waters had "Bad" ecological status (LES), only the waters of Danube region had "High" environmental class status. In 2016 the coastal waters of Dniester region had "Bad" environmental class status at all stations as well as water from upper mixed layer. Central waters had "Bad" water quality. The waters of the Danube region also had "High" environmental class status at all stations. The waters near the Dnieper had "Poor", "Moderate" or "Bad" environmental class status. In the summer period of the year 2017, the coastal waters of DniesterDanube district had "Moderate" environmental class status. The waters near the Dnieper region had "High" environmental quality class. Mixing waters showed "Bad" water quality and waters of Zernov's Phyllophora Field had "Poor" and "Bad" environmental class status. Only the waters of Odessa region had "High" environmental class status at all stations. In spring 2017 all stations of Zernov's Phyllophora Field showed "Bad" water quality class status. As a result of monitoring for 2016, 2017 and 2019, the environmental class status in most of the investigated aquatoria showed a "Bad" quality class, rarely "Moderate" or "Poor", "High" class of water quality was noted only in the Danube region (in 2019 and 2016) and in the Odessa region (2017, Fig. 10, Table 4, 5 and 6).

Table 4

Environmental class status (IZI) of the investigated aquatoria in 2019

\begin{tabular}{|c|c|c|c|c|c|}
\hline \multirow[b]{2}{*}{ Subregion } & \multirow{2}{*}{$\begin{array}{l}\text { Index of } \\
\text { Shannon } \\
\text { (average) }\end{array}$} & \multicolumn{2}{|c|}{ Summer } & \multicolumn{2}{|c|}{ Autumn } \\
\hline & & $\begin{array}{c}\text { ecological } \\
\text { quality ratio }\end{array}$ & $\begin{array}{c}\text { ecological } \\
\text { class status }\end{array}$ & $\begin{array}{c}\text { ecological } \\
\text { quality ratio }\end{array}$ & $\begin{array}{l}\text { ecological } \\
\text { class status }\end{array}$ \\
\hline Dnieper region & 2.504 & - & - & 0.640 & "Bad"' \\
\hline Dniester region & 2.449 & - & - & 0.748 & “Bad” \\
\hline Odessa Bay & 2.571 & - & - & 0.750 & “Bad” \\
\hline Danube region & 2.804 & 0.905 & "High" & - & - \\
\hline $\begin{array}{l}\text { Zmeiny Island } \\
\text { region }\end{array}$ & 2.207 & - & - & 0.588 & “'Bad” \\
\hline $\begin{array}{l}\text { Zernov's } \\
\text { Phyllophora Field }\end{array}$ & 2.981 & - & - & 0.589 & “Bad”' \\
\hline Tendra Spit region & 2.373 & - & - & 0.819 & “Bad” \\
\hline Damping region & 2.882 & - & - & 0.747 & "Bad" \\
\hline
\end{tabular}

Note: "-“-samples were not taken.

Table 5

Environmental class status (IZI) and threshold value of the investigated aquatoria in 2016

\begin{tabular}{lcc}
\hline \multirow{2}{*}{ Subregion } & \multicolumn{2}{c}{ Spring } \\
\cline { 2 - 3 } & ecological quality ratio & ecological class status \\
\hline Dnieper region & 0.806 & "Moderate" \\
Dniester region & 0.708 & "Bad" \\
Danube region & 0.642 & "High" \\
Mixing & 0.772 & "Bad" \\
Central & 0.809 & "Bad" \\
\hline
\end{tabular}

In Georgia, the Integrated Zooplankton Indices (IZI) are used for assessment of the ecological status of the Georgian Black Sea coast and the shelf zone.

In Georgian waters the IZI ranged from 0.552 to 0.962 in 2016 and its value corresponded to GES on all stations. IZI slightly increased on CW08, CW09 and CW13 water bodies, while on CW07 and CW10 it decreased in 2018, thus their status changed to Not GES. During assess- ment process of coastal waters, the IZI indicator varied slightly over the years; it is noteworthy that the index corresponds to good GES quality at all monitoring stations (Fig. 11).
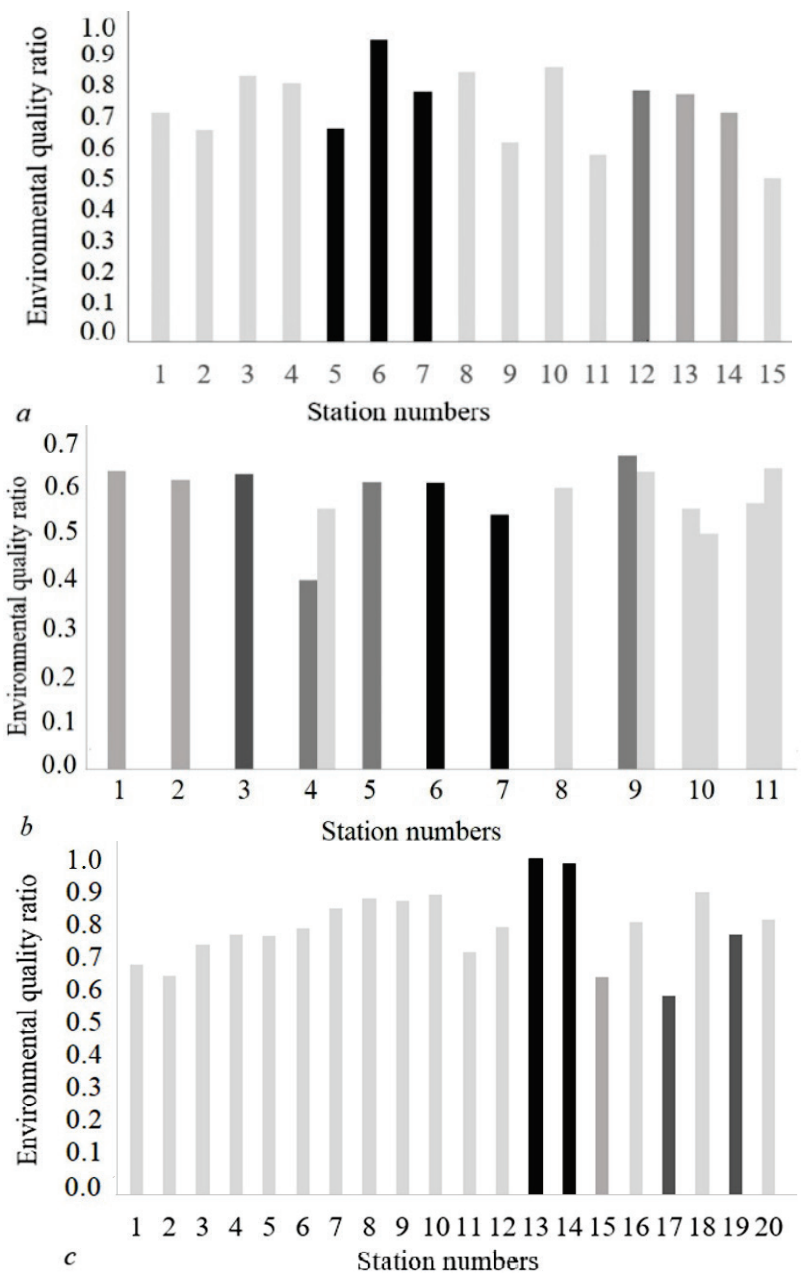

Fig. 10. Environmental class status of the investigated aquatoria: $a$-in 2016, $b-2017, c-2019$ years; axis X-numbers of samples on maps, axis $\mathrm{Y}$ - environmental quality ratio (EQR): — - "High", _ - "Good", __"Moderate", _ _"Poor", _-Bad"

Table 6

Environmental class status (IZI) and threshold value of the investigated aquatoria in 2017

\begin{tabular}{lcccc}
\hline \multirow{2}{*}{ Subregion } & \multicolumn{2}{c}{ Spring } & \multicolumn{2}{c}{ Summer } \\
\cline { 2 - 5 } & $\begin{array}{c}\text { ecological } \\
\text { quality ratio }\end{array}$ & $\begin{array}{c}\text { ecological } \\
\text { class status }\end{array}$ & $\begin{array}{c}\text { ecological } \\
\text { quality ratio }\end{array}$ & $\begin{array}{c}\text { ecological } \\
\text { class status }\end{array}$ \\
\hline Mixing & - & - & 0.593 & "Bad" \\
Danube region & - & - & 0.523 & "Poor" \\
Dnieper region & - & - & 0.660 & "High" \\
Odessa Bay & - & - & 0.555 & "High" \\
Zernov's Phyllophora Field & 0.577 & "Bad" & 0.585 & "Bad" \\
\hline
\end{tabular}

Note: see Table 4.

In open waters environmental class status in 2019 was much better than in 2016 and similar to that in 2017, when most of them had "High" (GES) environmental class status (Fig. 12, Tables 7, 8, 9). In comparison with data for 2016 and 2017 environmental class status of the investigated aquatoria in 2019 was much better than in 2016 and similar to that in 2017 when most of them had "High" environmental class status.

According to the zooplankton metrics and IZI integral index all investigated aquatoria in 2019 had "High" ecological status (GES). In 2016 almost all of the investigated aquatoria had "Bad" ecological status (NOT GES). The coastal waters of upper mixed layer and deep waters had "Bad" environmental class status at all stations. Only the thermocline layer showed "Moderate" water quality. In 2017 the coastal waters of upper 
mixed layer, Dniester-Danube district, the shelf zone of the Danube area and thermocline layer had "High" environmental class status at all stations. Only deep waters had "Moderate" and "Bad" environmental quality class. As we can see from the Figure 12, in 2016 not one of the investigated aquatoria had "High" or "Good" environmental class status.
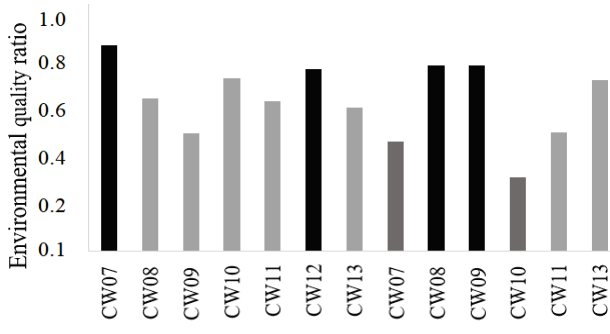

2016

2018

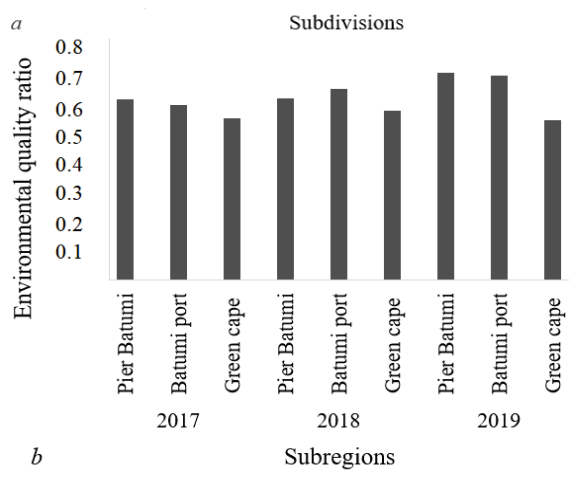

Fig. 11. Environmental status class of the Georgian aquatoria in 2016, 2017, 2018 and 2019 years: $a$ - subdivisions, $b$-subregions; black - "High", dark grey - "Good", light grey - "Moderate"
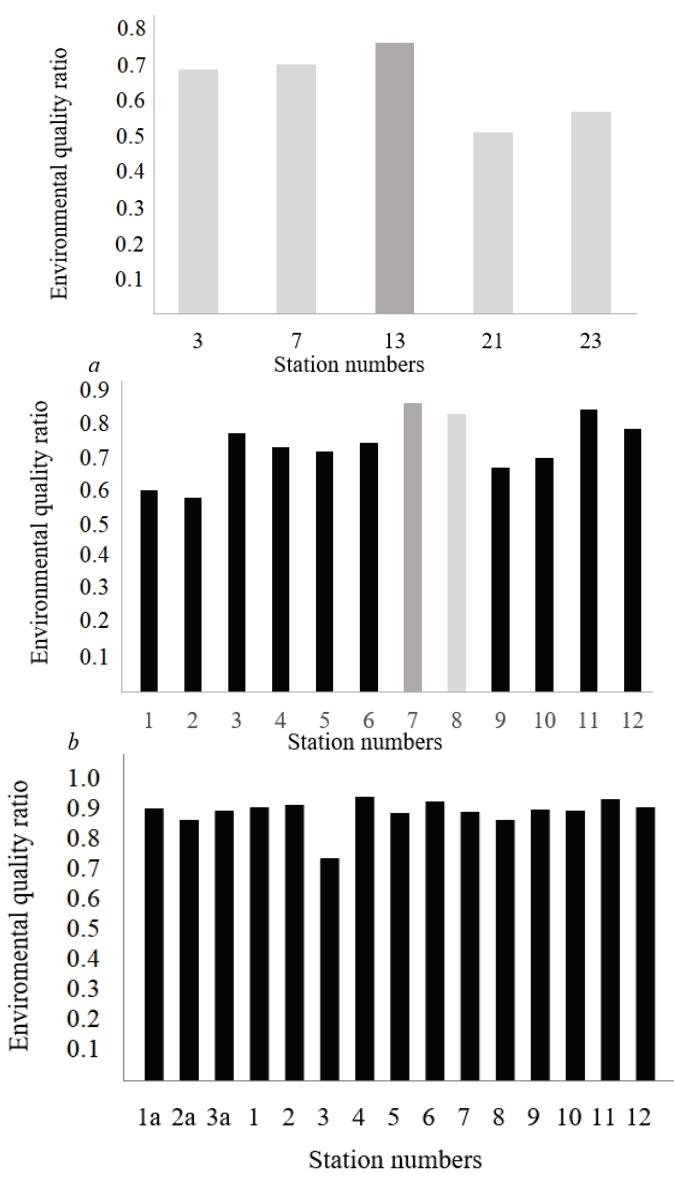

Fig. 12. Environmental class status of the investigated aquatoria of open waters: $a$-in 2016, $b-2017, c-2019$ years; axis X - numbers of samples on maps, axis $\mathrm{Y}$ - environmental quality ratio (EQR); black - "High", dark grey - "Moderate", light grey -"Bad"
Table 7

Environmental class status (IZI) and Threshold value of the investigated aquatoria in summer 2019

\begin{tabular}{lccc}
\hline \multicolumn{1}{c}{ Subregion } & $\begin{array}{c}\text { Index of } \\
\text { Shannon (average) }\end{array}$ & $\begin{array}{c}\text { Ecological } \\
\text { quality ratio }\end{array}$ & $\begin{array}{c}\text { Ecological } \\
\text { class status }\end{array}$ \\
\hline Zmeiny Island region & 2.641 & 0.889 & "High" \\
Damping region & 2.653 & 0.872 & "High" \\
Odessa region & 2.252 & 0.880 & "High" \\
Upper mixed layer & 2.403 & 0.869 & "High" \\
(shelf zone, surface layer) & 1.122 & 0.889 & "High" \\
Open water & & & \\
\hline
\end{tabular}

Note: see in Table 1.

Table 8

Environmental class status (IZI) and Threshold value of the investigated aquatoria in 2016

\begin{tabular}{lcccc}
\hline \multirow{2}{*}{ Subregion } & \multicolumn{2}{c}{ Spring } & \multicolumn{2}{c}{ Summer } \\
\cline { 2 - 5 } & $\begin{array}{c}\text { ecological } \\
\text { quality ratio }\end{array}$ & $\begin{array}{c}\text { ecological } \\
\text { class status }\end{array}$ & $\begin{array}{c}\text { ecological } \\
\text { quality ratio }\end{array}$ & $\begin{array}{c}\text { ecological } \\
\text { class status }\end{array}$ \\
\hline Upper mixed layer & 0.601 & "Bad" & 0.285 & "Bad" \\
Thermocline layer & - & - & 0.633 & "Moderate" \\
Deep waters & - & - & 0.364 & "Bad" \\
\hline
\end{tabular}

Note: see Table 4.

Table 9

Environmental class status (IZI) and Threshold value of the investigated aquatoria in 2017

\begin{tabular}{lcccc}
\hline \multirow{2}{*}{ Subregion } & \multicolumn{2}{c}{ Summer } & \multicolumn{2}{c}{ Autumn } \\
\cline { 2 - 5 } & $\begin{array}{l}\text { ecological } \\
\text { quality ratio }\end{array}$ & $\begin{array}{c}\text { ecological } \\
\text { status class }\end{array}$ & $\begin{array}{c}\text { ecological } \\
\text { quality ratio }\end{array}$ & $\begin{array}{c}\text { ecological } \\
\text { status class }\end{array}$ \\
\hline $\begin{array}{l}\text { Dniester-Danube } \\
\text { Shelf zone, surface layer, }\end{array}$ & 0.606 & "High" & - & - \\
$\begin{array}{l}\text { Danube area } \\
\text { Upper mixed layer }\end{array}$ & 0.680 & "High" & - & - \\
(shelf zone, surface layer) & 0.734 & "High" & - & - \\
$\begin{array}{l}\text { Thermocline layer } \\
\begin{array}{l}\text { Deep waters } \\
\text { Upper mixed layer }\end{array} \\
\text { (shelf zone, surface layer) }\end{array}$ & 0.735 & "High" & - & - \\
\hline
\end{tabular}

Note: see Table 4.

According to the zooplankton metrics and IZI integral index in 2019 most of investigated aquatoria had "Bad" ecological status (LES), only the waters of the Danube region had "High" environmental class status. In 2016 the coastal waters of the Dniester had "Bad" environmental class status at all stations as well as water from upper mixed layer. Central waters had "Bad" water quality. The waters of the Danube region also had "High" environmental class status at all stations. The waters near the Dnieper had "Poor", "Moderate" or "Bad" environmental class status. In the summer period of 2017, the coastal waters of Dniester-Danube district had "Moderate" and "Good" environmental class status. The waters near the Dnieper region had "Poor" environmental quality class. Mixing waters showed "Bad" water quality and waters of Zernov's Phyllophora Field had "Poor", and "Bad" environmental class status. Only waters of Odessa region had "High" environmental class status at all stations. In spring 2017 all stations of Zernov's Phyllophora Field showed "Bad" water quality class status. In the framework of the present Project in Ukrainian waters long-term changes of three indicator metrics of mesozooplankton (total biomass, \% of $N$. scintillans and Copepoda in total biomass) were studied in Odessa Bay and surrounding waters and in the Danube region (Fig. 13, 14). It is well seen that total zooplankton biomass and $\%$ of $N$. scintillans are clearly decreasing in Ukrainian waters and \% of Copepoda is increasing. These tendencies show positive changes in the forage base of commercial planktophagous fishes and ecological class status of the investigated aquatoria. In Georgian coastal waters \% of Copepoda amounted to average $32.7 \%, 42.4 \%$ and $40.1 \%$ in 2017,2018 and 2019 respectively. It fluctuated from $42.3 \%$ to $45.6 \%$ between 2017 and 2019 in the Green Cape Aquatorium (Fig. 16). All the data about assessment of environmental and ecological class status of the investigated aquatoria of the Black Sea based on zooplankton metrics, achieved during the execution of the project are summarized on maps on Figures 17 and 18. 

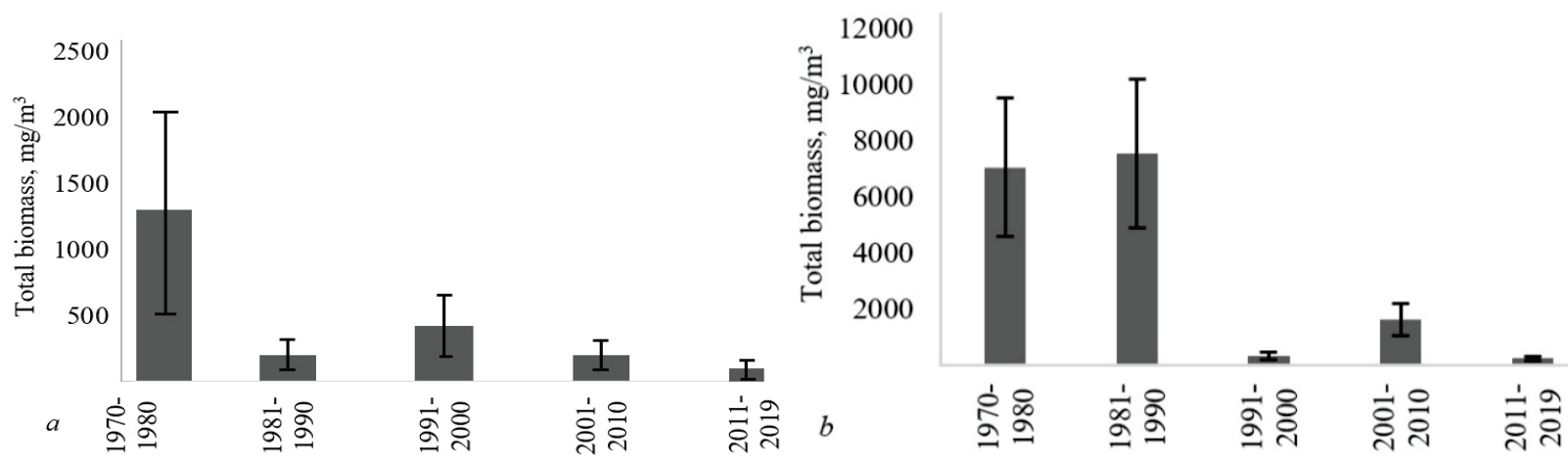

Fig. 13. Long-term changes of total biomass of mesozooplankton: $a$-in Odessa Bay ( $\mathrm{n}=35), b$ - in the Danube region $(\mathrm{n}=22)$; axis $\mathrm{X}$ - periods, axis $\mathrm{Y}$ - total biomass of zooplankton $\left(\mathrm{mg} / \mathrm{m}^{3}\right) ; \mathrm{x} \pm \mathrm{SD}$

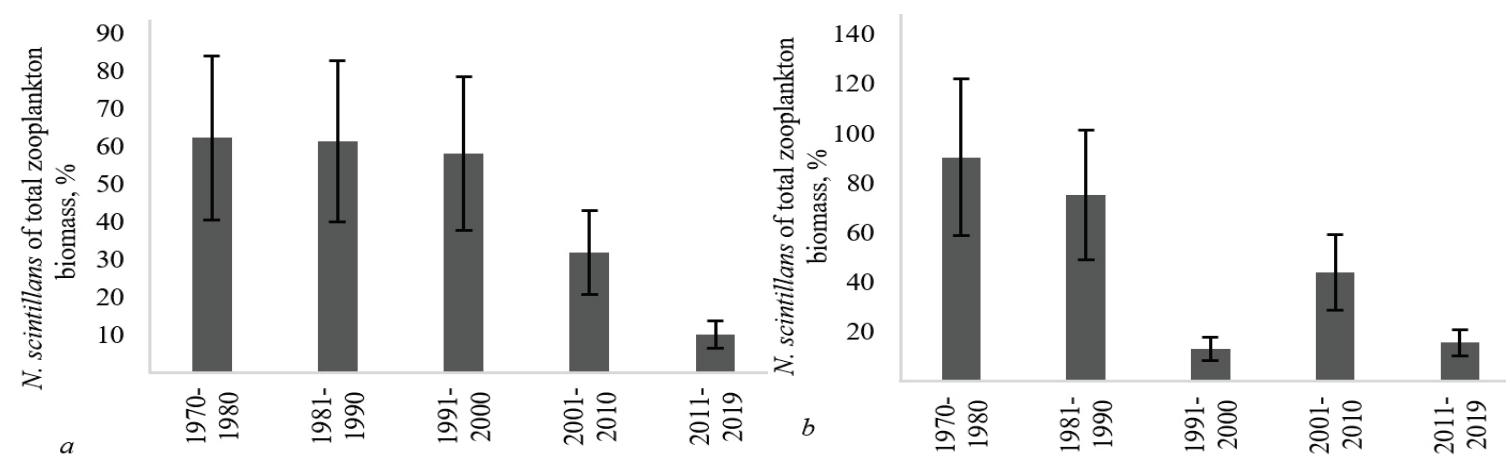

Fig. 14. Long-term changes percentage of $N$. scintillans of total biomass of mesozooplankton: $a$-in Odessa Bay $(\mathrm{n}=35), b$ - in the Danube region $(\mathrm{n}=22)$; axis $\mathrm{X}$ - periods, axis $\mathrm{Y}-$ N. scintillans of total biomass $(\%) ; \mathrm{x} \pm \mathrm{SD}$

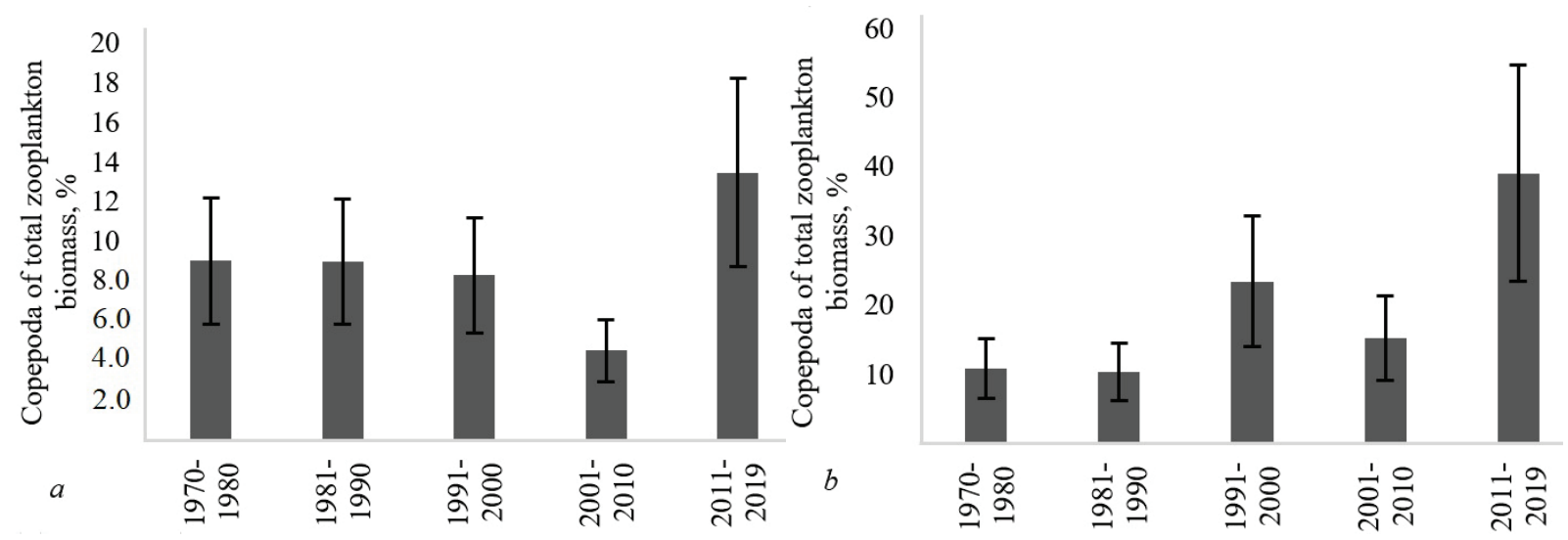

Fig. 15. Long-term changes percentage of Copepoda of total biomass of zooplankton:

$a$-in Odessa Bay ( $\mathrm{n}=35), b$-in the Danube region ( $\mathrm{n}=22)$; axis $\mathrm{X}$ - periods, axis $\mathrm{Y}$-Copepoda of total zooplankton biomass (\%); $\pm \mathrm{SD}$

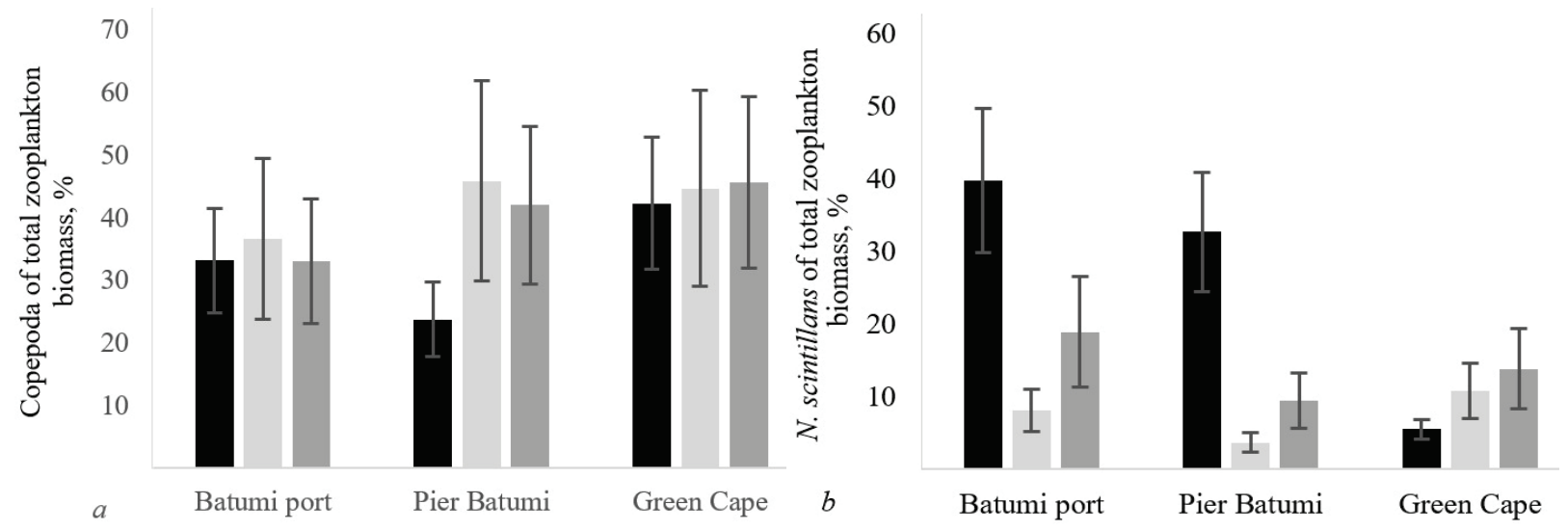

Fig. 16. Percentage of Copepoda $(a)$ and $N$. scintillans (b) of total zooplankton biomass in Georgian waters: black $-2017(\mathrm{n}=12)$, light grey $-2018(\mathrm{n}=10)$, dark grey $-2019(\mathrm{n}=13) ; \mathrm{x} \pm \mathrm{SD}$ 

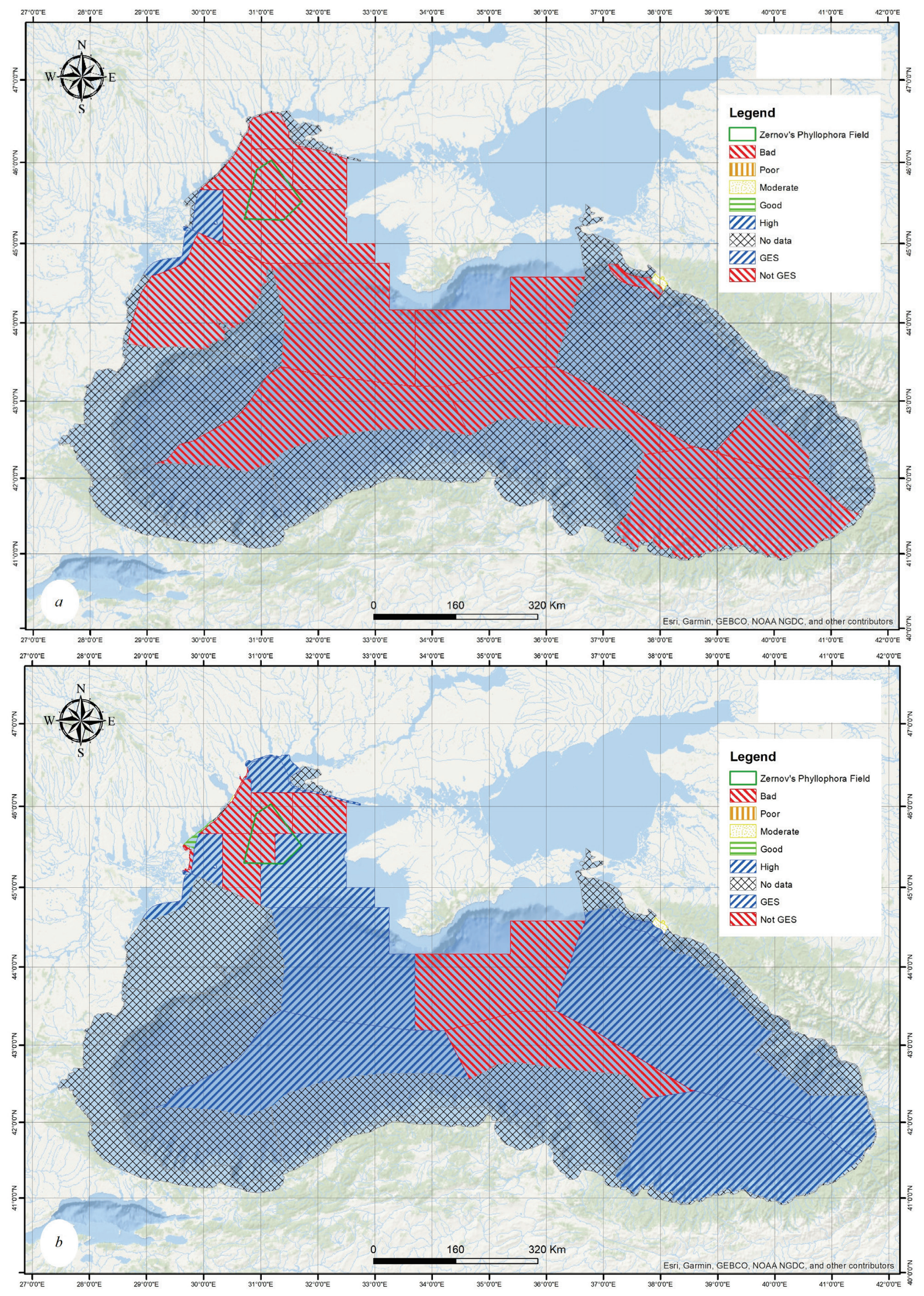

Fig. 17. Environmental and ecological class status of the investigated aquatoria of the Black Sea based on zooplankton metrics: $a$-in 2016, $b$ - in 2017 


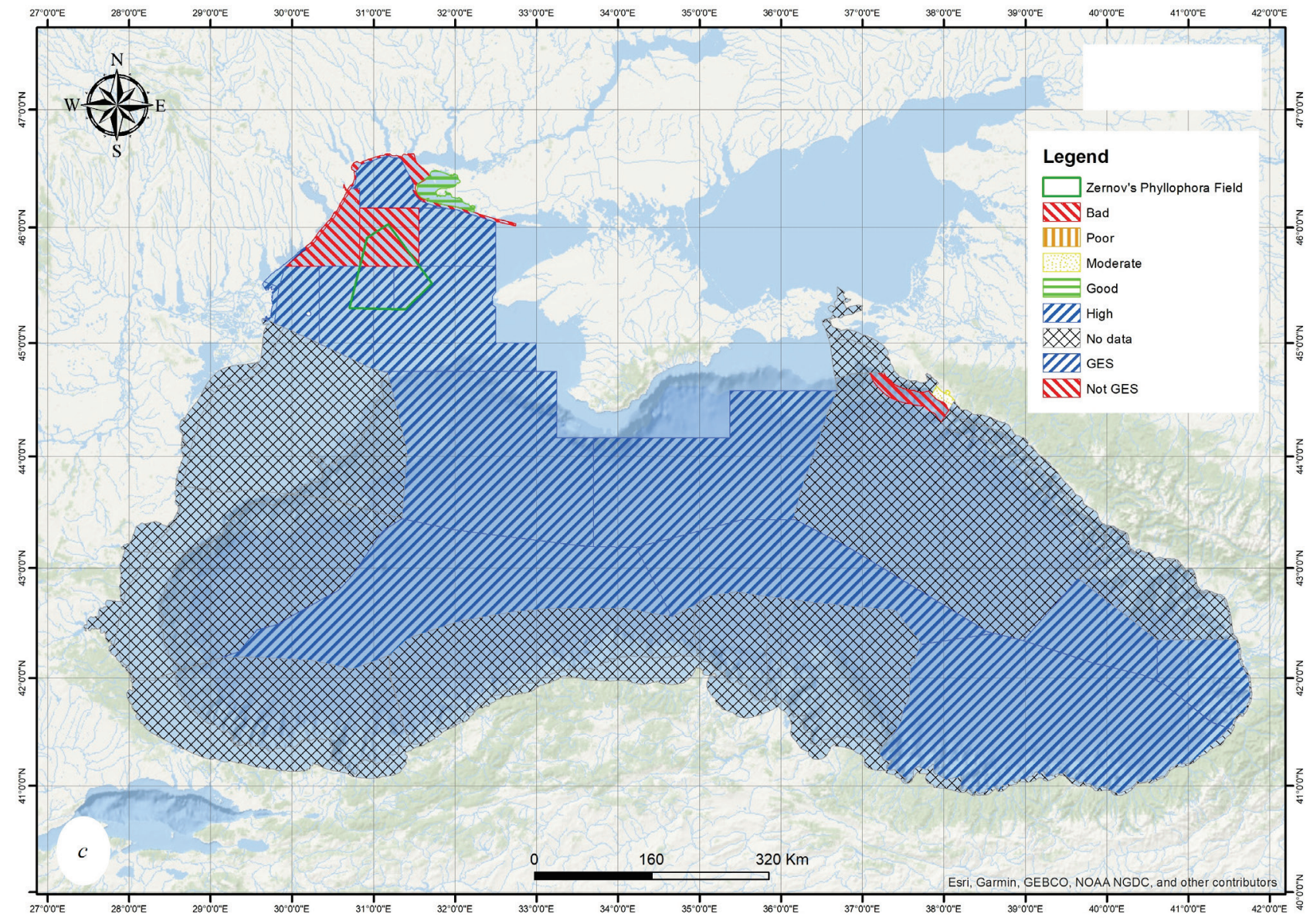

Fig. 18. Environmental and ecological class status of the investigated aquatoria of the Black Sea based on zooplankton metrics in 2019

\section{Discussion}

During the last three decades anthropogenic eutrophication has been identified as a key ecological problem for the coastal Black Sea region (especially its north-western part subjected to the strong influence of freshwater input), resulting in dramatic alterations in the chemical and biological regimes (Zaitzev, 1992; Moncheva et al., 2002; Jeppesen et al., 2011). The main changes in the zooplankton community in the northwestern part of the Black Sea in the XX (Koval, 1984; Zaitsev, 1993; Zaitsev \& Alexandrov, 1997) and at the beginning of XXI centuries were analysed by many scientists (Kovalev et al., 2008; Kovalev et al., 2001; Snigirov et al., 2018) and L. N. Polishchuk (Vorobjova et al., 1996; Polishchuk \& Nastenko, 2006). He divided the history of the pelagic ecosystem into three periods: period of "ecological norm" (before anthropogenic eutrophication, prior to 1970), period of eutrophication and hypereutrophication (1970-2004 years) and the period of de-eutrophication and establishment of a new "ecological norm" (after 2005). The first period was characterized by dominance of Copepoda ( $\geq 45 \%$ of the total zooplankton biomass) and the following values of the biomass of zooplankton: in spring $150-400 \mathrm{mg} / \mathrm{m}^{3}$, in summer $350-900 \mathrm{mg} / \mathrm{m}^{3}$, in autumn -150 $350 \mathrm{mg} / \mathrm{m}^{3}$, the percentage of $N$. scintillans in total biomass did not exceed 30\% (Selifonova, 2009; Nikishina et al., 2011; Isinibilir et al., 2014). During the second period the percentage of Copepoda decreased, the percentage of $N$. scintillans increased up to $95-98 \%$ and total biomass of zooplankton increased in 9-28 times (Polishchuk \& Nastenko, 2006). The third period is characterized by decreasing of total biomass of zooplankton and percentage of $N$. scintillans and increasing of the percentage of Copepoda (Nawata \& Sibaoka, 1983; Mutlu, 2011).

Over the past several decades, the Black Sea ecosystem has been in a dynamic state (Snigirov et al., 2018). For various reasons, the development of some species decreases or increases, others disappear, and new ones are introduced to the ecosystem (Alexandrov \& Kharytonova, 2019). The state of development of zooplankton, as in previous decades, continues to depend on the amount of river flows, which affects the quality of the marine environment in the Odessa Bay and on the entire coast (Alexandrov et al., 2017; Kharytonova et al., 2020). Although a considerable number of studies have been conducted on this issue in the Black Sea, which has been exposed to very rapid changes in recent years, there are few studies about the year round abundance and the seasonal distribution of zooplankton in this region (Fashchu6k, 2011; Grishin \& Shlyakhov, 2012). In the last decade, some signs of the improvement of the sea ecosystem have been noted, which is obviously associated with protective measures taken at the state and interstate levels (Kazanci et al., 2010). Changes in the ecosystem of the Black Sea are observed against the background of climatic changes, which significantly affect the formation of the river runoff regime, the thermohaline and dynamic state of waters and, in general, the marine ecosystem (Korotaev, 2009; Robu et al., 2015; Pokazeev et al., 2021).

Eutrophication and the associated violation of the oxygen regime are among of the most unfavourable factors in the life of the Black Sea ecosystem. The annual disturbance of the oxygen regime in deep waters significantly destroys the ecosystem of the vast shallow-water shelf (Osadchiev \& Korshenko, 2017; Kharytonova, 2019). The process, which began actively in the 1970, continues to this day (Zaitsev, 1993; Alexandrov \& Zaitsev, 1998).

Several indicators which are representatives of a particular state of quality of the environment constitute biotic indices. Multimetric biotic indices are necessary to analyze changes in various habitats over time. They are used to monitor habitat changes caused by anthropogenic effects. Because diversity is correlated with environmental quality diversity measures are playing an increasing role in environmental assessment (Alexandrova et al., 2007; Alpenidze, 2013; Matishov, 2014).

As mandated by the EU Marine Strategy Framework Directive (MSFD 2008), all European states should assess the environmental status of their territorial waters and develop strategies to achieve "good environmental status" (Borja et al., 2006; Atkins, 2011; Micheli, 2013).

As we can see, the best ecological class status was in 2019 and the worst - in 2016. So, according to the historical data and materials collected 
during the execution of the project the main tendencies in changes of the mesozooplankton community in the Black Sea are decrease in the percentage of $N$. scintillans in total zooplankton biomass and increase in the percentage of Copepoda. Those tendencies indicate decreasing of the pressure of the negative eutrophication factor (Vinogradov et al., 2018; Pokazeev et al., 2021) and show positive changes in the forage base of commercial planktophagous fishes and ecological status of the Black Sea waters. These tendencies are in good agreement with the conclusion of Polishchuk (Polischuk \& Nastenko, 2006) that the Black Sea ecosystem is in a state of de-eutrophication and the establishment of a new "ecological norm".

\section{Conclusions}

In the deep basin of the Ukranian and Georgian parts of the the Black Sea, in 2019 the average biomass of forage zooplankton was the highest among the three years studied. The number and biomass of zooplankton clearly decrease from the water-surface to the depth. At most of the stations, organisms of the forage zooplankton played the dominant role in forming of zooplankton biomass.

In the north-western part of the Black Sea and Zernov's Phyllophora Field in 2019 taxonomic composition of zooplankton was more diverse than in previous years (27 taxa in 2016, 26 in 2017). Most of them belong to the forage zooplankton for fish. Average number and biomass of zooplankton in 2019 was similar to those in $2016\left(10,299 \mathrm{ind} . \mathrm{m}^{3}\right.$ and 182.62 $\mathrm{mg} / \mathrm{m}^{3}$ ) and much higher than in 2017 (1714 ind $/ \mathrm{m}^{3}$ and $\left.29.99 \mathrm{mg} / \mathrm{m}^{3}\right)$. At most of the stations the dominant taxa by number and biomass were Copepoda, Cladocera and larvae of benthic invertebrates.

The mesozooplankton of the coastal waters of Georgian Black Sea are more diverse than the zooplankton community of the shelf and open sea area. Species which are indicators of an improvement in the state of the marine environment have increased in the coastal waters of Georgia over the past years. There was a significant decrease in the abundance of zooplankton and biomass from 2017 to 2019.

As a result of monitoring for 2016, 2017 and 2019, in the deep basin of the Ukranian and Georgian parts of the Black Sea the best water quality was observed in the summer of 2019 (all stations) and at most of the stations in 2017. The worst water quality among three years was found in 2016. In the north-western part of the Black Sea and Zernov's Phyllophora Field the environmental class status in most of the investigated aquatories showed a "Bad" quality class, rarely "Moderate" or "Poor", "High" class of water quality was noted only in the Danube region (in 2019 and 2016) and in the Odessa region (2017).

The integrated zooplankton index IZI is quite variable in the shelf part of the Black Sea of Georgia. It ranged from 0.552 to 0.962 in 2016 and its value corresponded to GES on all stations. IZI slightly increased on CW08, CW09 and CW13 water bodies, while on CW07 and CW10 it decreased in 2018, thus their status changed to Not GES. During the assessment process of coastal waters, the IZI indicator varied slightly over the years. It is noteworthy that the index corresponds to good GES quality at all monitoring stations.

Good water quality (GES) for all seasons (spring, summer, autumn) by zooplankton biomass was noted in the Northwestern Black Sea Bays. In the Danube Avandelta area, good quality was observed in spring. In other periods of the year, in areas of the Deepwater Shelf, the Shallow Shelf and the Danube-Dnieper interfluve coastal waters the water quality was "Poor" (NotGES).

By the biomass of Copepoda (\%), good water quality (GES) is noted in the Deepwater Shelf, the Shallow Shelf, the Danube-Dnieper interfluve coastal waters and the Danube Avandelta. The Northwestern Black Sea Bays subregion had "Poor" ecological status (NotGES).

By the IZI index, the subdivision North-Western Black Sea Bays had "Good", "Poor" and "Medium" water quality in spring, summer and autumn respectively. The subdivisions Deepwater Shelf and Shallow Shelf had bad water quality. The subdivision Danube-Dnieper interfluve coastal waters had high water quality. The Danube Avandelta area had high good and high water quality in spring, summer and autumn respectively. The main tendencies in changes of the mesozooplankton community in the Black Sea are decrease in the percentage of N. scintillans in total zooplankton biomass and increase in the percentage of Copepoda. Those tendencies indicate decreasing of the pressure of the negative eutrophication factor and show positive changes in the forage base of commercial planktophagous fishes and ecological status of the Black Sea waters.

\section{References}

Aleksandrov, B. G., \& Zaitsev, Y. P. (1998). Black sea biodiversity in eutrophication conditions. In: Kotlyakov, V., Uppenbrink, M., \& Metreveli, V. (Ed.). Conservation of the biological diversity as a prerequisite for sustainable development in the Black sea region. Nato Science Partnership Subseries, 46, 221-234.

Aleksndrov, B. G., Vorobeva, L. V., Kulakova, I. I., \& Sinegub, I. A. (2017). Odesskiy region Chernogo morya: Gidrobiologiya pelagiali i bentali [Odessa region of the Black Sea: Hydrobiology of pelagials and benthals]. Astroprint, Odessa (in Russian).

Alexandrov, B., Minicheva, G., \& Zaitsev, Y. (2017). European approaches and adaptation to expansion and monitoring in Ukraine. In: Goriup, P. D. (Ed.). Black Sea network of marine protected areas. John Wiley \& Sons Ltd., Chichester. Pp. 227-246.

Alexandrova, V., Moncheva, S., Slabakova, N., Stefanova, K., \& Doncheva, V. (2007). Application of biotic indices and body size descriptors of phyto- and zooplankton communities in Varna lagoon for ecological status assessment. Transitional Waters Bulletin, 3, 17-21.

Alpenidze, M., Diasamidze, R., Kordzakhia, G., Jomidava, R., \& Tsitskishvili, M. (2013). Complex investigation of ecological state of the Black sea and actions for its protection. In: Veziroğlu, A., \& Tsitskishvil, M. (Ed.). Black sea energy resource development and hydrogen energy problems. NATO science for peace and security series, environmental security. Springer, Dordrecht. Pp. 1-7.

Arashkevich, E. G., Stefanova, K., Bandelj, V., Siokou, I., Terbiyik, K. T., Ak Orek, Y., Timofte, F., Timonin, A., \& Solidoro, C. (2014). Mesozooplankton in the open Black sea: Regional and seasonal characteristics. Joumal of Marine Systems, 135, 81-96.

Atkins, J. P., Burdon, D., Elliott, M., \& Gregory, A. J. (2011). Management of the marine environment: Integrating ecosystem services and societal benefits with the DPSIR framework in a systems approach. Marine Pollution Bulletin, 62, 215-226.

Bat, L., Gökkurt, O., Sezgin, M., Üstün, F., \& Sahin, F. (2009). Evaluation of the Black Sea land based sources of pollution the coastal region of Turkey. The Open Marine Biology Journal, 3, 112-124.

Borja, A., Galparsoro, I., Solaun, O., Muxika, I., Tello, E. M., Uriarte, A., \& Valencia, V. (2006). The European Water Framework Directive and the DPSIR, a methodological approach to assess the risk failing to achieve good ecological status. Estuarine, Coastal and Shelf Science 66, 84-96.

Fashchuk, D. Y. (2011). Gas production on the North-Western shelf of the Black Sea: Scales, geographic and ecological conditions, consequences and their forecast. In: Fashchuk, D. Y. (Ed.). Marine ecological geography. Environmental science and engineering. Springer, Heidelberg. Pp. 237-316.

Gordina, A. D., Pavlova, E. V., Ovsyany, E. I., Wilson, J. G., Kemp, R. B., \& Romanov, A. S. (2001). Long-term changes in Sevastopol Bay (the Black Sea) with particular reference to the ichthyoplankton and zooplankton. Estuarine, Coastal and Shelf Science, 53(1), 1-13.

Grishin, A. N., \& Shlyakhov, V. A. (2012). Effect of modern changes in the pelagial of the Black Sea on the state of fishery. Ichthyology, 52, 613-618.

Isinibilir, M., Hubareva, E., \& Svetlichny, L. (2014). Interpopulation dynamics between Acartia clause (Copepoda) and Noctiluca scintillans (Dinoflagellata) in the Bosphorus area of the Black and the Marmara Seas. Italian Journal of Zoology, 81(3), 451-456.

Jeppesen, E., Noges, P., Davidson, T. A., Haberman, J., Noges, T., Blank, K., Lauridsen, T. L., Søndergaard, M., Sayer, C., Laugaste, R., Johansson, L. S., Bjerring, R., \& Amsinck, S. L. (2011). Zooplankton as indicators in lakes: A scientific-based plea for including zooplankton in the ecological quality assessment of lakes according to the European Water Framework Directive (WFD). Hydrobiologia, 676, 279-297.

Kazanci, N., Ekingen, P., Turkmen, G., Ertunv, O., Dugel, M., \& Gultutan, Y. (2010). Assessment of ecological quality of Aksu Stream (Giresun, Turkey) in Eastern Black Sea region by using Water Framework Directive (WFD) methods based on benthic macroinvertebrates. Review of Hydrobiology Research Article, 3(2), 165-184.

Kharytonova, J. V. (2019). Analiz perekhidnykh vod Ukrainskoho shelfu Chornoho moria za pokaznykamy zooplanktonu (na prykladi delty Dunaiu) [Analysis of transition waters of the Ukranian Black sea shelf by zooplankton indicators (on example of the Danube Delta)]. Visnik of the Odessa National University, Seriya Biology, 45, 88-96 (in Ukrainian).

Kharytonova, Y. V., \& Nabokin, M. V. (2020). Zooplankton of the North-Western part of the Black Sea in 2016-2019 and assessment of the quality of the environment by its indicators. In: Kempinsk, U., Henryk, S., Vozhehova, R. (Eds.). 
Scientific Developments of Ukraine and EU in the Area of Natural Sciences. Baltija Publishing, Riga. 685-700.

Kharytonova, Y. V., Nabokin, M. V., \& Dyadychko, V. G. (2020). Zooplankton vidkrytoi chastyny Chornoho moria v 2016-2019 rr. ta otsinka yakosti vodnoho seredovyshcha za yoho pokaznykamy [Zooplankton of the open part of the Black Sea in 2016-2019 and assessment of the quality of the aquatic environment-according to its indicators]. Ecological Sciences, 29, 87-94 (in Ukrainian).

Korotaev, G. K. (2009). Black Sea forecasting system: Current state and prospect. In: Groisman, P. Y., \& Ivanov, S. V. (Ed.). Regional aspects of climate-terrestrialhydrologic interactions in non-boreal Eastern Europe. NATO science for peace and security, environmental security. Springer, Dordrecht. Pp. 233-243.

Koval, L. G. (1984). Zoo- i makrozooplankton Chernogo morya [Zoo- and macrozooplankton of the Black Sea]. Naukova Dumka, Kiev (in Russian).

Kovalev, A., Mazzocchi, M., Siokou, I., \& Kidets, A. (2001). Zooplankton of the Black Sea and the Eastern Mediterranean: Similarities and dissimilarities. Mediterranean Marine Science, 2(1), 69-78.

Kovalev, A., Niermann, U., Melnikov, V., Belokopitov, V., Uysal, Z., Kideys, A. E., Unsal, M., \& Altukhov, D. (1998). Long-term changes in the Black Sea zooplankton: The role of natural and anthropogenic factors. In: Ivanov, L., \& Oguz T. (Ed.). Ecosystem modelling as a management tool for the Black Sea. Kluwer Academicals Publishing. Pp. 221-235.

Loeva, I. D., Pavlenko, M. Yu., Orlova, I. G., \& Komorin, V. M. (2008). Polityka Ukrainy z okhorony pryrodnoho seredovyshcha Chornoho moria [Ukraine's policy on environmental protection of the Black Sea]. Black Sea Ecological Bulletin, 30, 7-13 (in Ukrainian).

Matishov, G. G., Matishov, D. G., \& Stepan'yan, O. V. (2014). Assessment of the modern state of the Black Sea ecosystem (Republic of Abkhazia). Doklady Earth Sciences, 454, 213-217.

Micheli, F., Halpern, S., Walbridge, S., Ciriaco, S., Ferretti, F., \& Fraschetti, S. (2013). Cumulative human impacts on Mediterranean and Black Sea marine ecosystems: Assessing current pressures and opportunities. PLoS One, 8(12), 79889.

Moncheva, S., Dontcheva, V., Shtereva, G., Kamburska, L., Malej, A., \& Gorinstein, S. (2002). Application of eutrophication indices for assessment of the Bulgarian Black Sea coastal ecosystem ecological quality. Water Science Technology, 46(8), 19-28.

Moncheva, S., Racheva, E., Kamburska, L., \& D'Hernoncourt, J. (2012). Environmental and management constraints on tourism in Varna Bay, Bulgarian Black Sea coast. Ecology and Society 17(3), 35.

Mordukhai-Boltovsky, F. D. (1968). Opredelitel' fauny Chernogo i Azovskogo morey: Svobodnozhivuschie bespozvonochnyie. Prosteyshie, gubki, kishechnopolostnyie, chervi, schupaltsevyie [Key to the fauna of the Black and Azov seas: Free-living invertebrates. Protozoa, sponges, coelenterates, worms, tentacles] Naukova Dumka, Kiev (in Russian).

Mordukhai-Boltovsky, F. D. (1969). Opredelitel' fauny Chernogo i Azovskogo morey: Svobodnozhivuschie bespozvonochnyie. Rakoobraznye [Key to the fauna of the Black and Azov seas: Free-living invertebrates. Crustaceans]. Naukova Dumka, Kiev (in Russian).

Mordukhai-Boltovsky, F. D. (1972). Opredelitel' fauny Chernogo i Azovskogo morey: Svobodnozhivuschie bespozvonochnyie. Chlenistonogie (krome rakobraznyih), molyuski, iglokozhie, schetinkochelyustnyie, hordovyie [Key to the fauna of the Black and Azov seas. Free-living invertebrates. Arthropods (except crustaceans), molluscs, echinoderms, chaetae, chordates]. Naukova Dumka, Kiev (in Russian).

Mutlu, E. (2001). Distribution and abundance of moon jellyfish (Aurelia aurita) and its zooplankton food in the Black Sea. Marine Biology, 138, 329-339.

Nawata, T., \& Sibaoka, T. (1983). Experimental induction of feeding behavior in Noctiluca miliaris. Protoplasma, 115, 34 42

Nikishina, A. B., Drits, A. V., \& Vasilyeva, Y. V. (2011). Role of the Noctiluca scintillans population in the trophic dynamics of the Black Sea plankton over the spring period. Oceanology, 51, 1029-1039.
O’Higgins, T., Farmer, A., Daskalov, G., Knudsen, S., \& Mee, L. (2014). Achieving good environmental status in the Black Sea: Scale mismatches in environmental management. Ecology and Society, 19(3), 1-54.

Osadchiev, A., \& Korshenko, E. (2017). Small river plumes off the northeastern coast of the Black Sea under average climatic and flooding discharge conditions, Ocean Science, 13, 465-482.

Ozdemir, G., \& Ak, O. (2012). The qualitative and quantitative distribution of the zooplankton in the Southeastern Black Sea (Trabzon coast). Mediterranean Environment, 18(3), 279-298.

Öztürk, M., Özdemir, F., \& Yücel, E. (1997). An overview of the environmental issues in the Black Sea region. In: Glantz, M. H., \& Zonn, I. S. (Ed.). Scientific, environmental, and political issues in the Circum-Caspian region. NATO ASI Series. Springer, Dordrecht. 29, 213-226.

Pokazeev, K., Sovga, E., \& Chaplina, T. (2021). Main natural and anthropogenic sources of pollution of the Black Sea, its shelf zones and small water reservoirs. In: Pokazeev, K., Sovga, E., Chaplina, T. (Eds.). Pollution in the Black Sea. Springer, Cham. Pp. 97-141.

Polischuk, L. N., \& Nastenko, E. V. (2006). Mezo- i makrozooplankton [Mezo- i makrozooplankton]. In: Zaitsev, Y. P., Aleksandrov, B. G., \& Minicheva, G. G. (Ed.). North-western part of the Black Sea: Biology and ecology. Naukova Dumka, Kiev. Pp. 229-237 (in Russian).

Robu, B., Jitar, O., Teodosiu, C., Strungaru, S., Nicoara, M., \& Plavan, G. (2015). Environmental impact and risk assessment of the main pollution sourses from the Romanian Black Sea coast. Environmental Engineering and Management Journal, 14(2), 331-340.

Rudneva, I., \& Petzold-Bradley, E. (2001). Environment and security challenges in the Black Sea region. In: Petzold-Bradley, E., Carius, A., \& Vincze, A. (Ed.). Responding to environmental conflicts: Implications for theory and practice. NATO Science. Springer, Dordrecht. 78, 189-207.

Salazkin, A. A., Ivanova, M. B., \& Ogorodnikova, V. A. (1984). Metodicheskie rekomendatsii po sboru i obrabotke materialov pri gidrobiologicheskih issledovaniyah. Zooplankton i ego produktsiya [Methodological recommendations for the collection and processing of materials in hydrobiological research. Zooplankton and its products]. National Research Institute of Lake and River Fisheries, Leningrad (in Russian).

Selifonova, Z. P. (2009). Oithona brevicornis Giesbrecht (Copepoda, Cyclopoida) in harborages of the northeastern part of the Black Sea shelf. Inland Water Biology, 2, 30-32.

Snigirov, S., Lyumkis, P., Medinets, V., Gazyetov, Y., Snigirov, P., Medinets, S., Abakumov, O., Pitsyk, V., Svitlychnyi, S., Kovalova, N., \& Soltys, I. (2018). Izuchenie mezozooplanktona Odesskogo zaliva v 2016-2017 gg. [Mesozooplankton study in Odessa Bay in 2016-2017]. Bulletin of Karazin Kharkiv National University, Series Ecology, 19, 39-55 (in Russian).

Stel'makh, L. V., Babich, I. I., \& Tugrul, S. (2009). Phytoplankton growth rate and zooplankton grazing in the westem part of the Black Sea in the autumn period. Oceanology, 49, 83-92.

Vinogradov, A. K., Bogatova, Y. I., \& Synegub, I. A. (2018). Pelagic zone subsystem of the marine ports aquatories. In: Vinogradov, A. K., Bogatova, Yu. I., Synegub, I. A. (Eds.). Ecology of marine ports of the Black and Azov Sea basin. Springer, Cham. Pp. 39-172.

Vinogradov, M. E., Lebedeva, L. P., \& Lukasheva, T. A. (2006). Condition of coastal mesoplankton communities in the northeastem area of the Black Sea in 2005. Oceanology, 46, 817-826.

Zaitsev, Y. P. (1992). Recent changes in the trophic structure of the Black Sea. Fisheries Oceanography, 1(2), 180-189.

Zaitsev, Y. P. (1993). Impact of eutrophication on the Black Sea fauna, studies and reviews. General Fisheries Council for the Mediterranean, 64, 63-86.

Zaitsev, Y. P., \& Alexandrov, B. G. (1997). Recent man-made changes in the Black Sea. In: Ozsoy, E., \& Mikaelyan, A. (Ed.). Ecosystem sensitivity to change: Black Sea, Baltic Sea and North Sea. Nato Science Partnership Subseries. Springer, Dordrecht. Vol. 27, 25-31. 